\title{
The MRL/lpr Mouse Strain as a Model for Neuropsychiatric Systemic Lupus Erythematosus
}

\author{
Maria Gulinello ${ }^{1}$ and Chaim Putterman ${ }^{2}$ \\ ${ }^{1}$ Behavioral Core Facility, Department of Neuroscience, Albert Einstein College of Medicine, 1410 Pelham Pkwy S Kennedy 925, \\ Bronx, NY 10461, USA \\ ${ }^{2}$ Division of Rheumatology, Department of Medicine, Albert Einstein College of Medicine, Bronx, NY 10461, USA
}

Correspondence should be addressed to Maria Gulinello, maria.gulinello@einstein.yu.edu

Received 27 September 2010; Accepted 28 December 2010

Academic Editor: Monica Fedele

Copyright (C) 2011 M. Gulinello and C. Putterman. This is an open access article distributed under the Creative Commons Attribution License, which permits unrestricted use, distribution, and reproduction in any medium, provided the original work is properly cited.

To date, CNS disease and neuropsychiatric symptoms of systemic lupus erythematosus (NP-SLE) have been understudied compared to end-organ failure and peripheral pathology. In this review, we focus on a specific mouse model of lupus and the ways in which this model reflects some of the most common manifestations and potential mechanisms of human NP-SLE. The mouse MRL lymphoproliferation strain (a.k.a. MRL/lpr) spontaneously develops the hallmark serological markers and peripheral pathologies typifying lupus in addition to displaying the cognitive and affective dysfunction characteristic of NP-SLE, which may be among the earliest symptoms of lupus. We suggest that although NP-SLE may share common mechanisms with peripheral organ pathology in lupus, especially in the latter stages of the disease, the immunologically privileged nature of the CNS indicates that early manifestations of particularly mood disorders maybe derived from some unique mechanisms. These include altered cytokine profiles that can activate astrocytes, microglia, and alter neuronal function before dysregulation of the blood-brain barrier and development of clinical autoantibody titres.

\section{Introduction}

Systemic lupus erythematosus (SLE) is an autoimmune disease that is typified by multiple abnormalities of the immune system, and which results in widespread pathology of multiple organs, including skin, kidney, heart, lungs, and joints. In addition to peripheral organ dysfunction in SLE, there is a high incidence of neuropsychiatric symptoms especially headaches, cognitive dysfunction, and psychiatric disorders [1], with roughly $40-70 \%$ of SLE patients demonstrating affective disorders [2]. Brain pathology, loss of integrity of the blood-brain barrier and autoantibodies are thought to play a role in neuropsychiatric systemic lupus erythematosus (NP-SLE), although some patients with behavioral symptoms have histologically normal brain tissue and no identifiable markers in serum or CSF [3-11].

Neuropsychiatric symptoms, particularly affective disorders, may be among some of the earliest manifestations of SLE [12-14]. Approximately $40 \%$ of the NP-SLE symptoms develop before the onset of SLE or at the time of diagnosis and about $60 \%$ within the first year of diagnosis [13, $15,16]$, indicating that neuropsychiatric symptoms are reliable indicators of disease activity and are often evident even before gross peripheral organ pathology occurs (in particular kidney disease). Symptoms of NP-SLE may also be independent of active disease in other organs [17-19]. This was found to be the case also in the animal model of lupus which is the subject of this paper, the MRL/lpr mouse, where depressive-like behavior is evident in young animals before significant levels of autoantibody titers and nephritis are evident $[14,20]$. There are obvious limits to the search for mechanisms of CNS disease in human patients, and furthermore the diagnosis is often made after lupus is in late stages of progression. Thus, murine models can offer many advantages to elucidate the early mechanisms of neuropsychiatric manifestations of NP-SLE and help to distinguish between CNS-specific mechanisms and nonspecific illness. In this paper we focus on a specific 
murine model of lupus, the MRL/lpr strain, and the ways in which this model reflects some of the most common manifestations of human NP-SLE. In addition, we discuss experimental data pointing to viable pathogenic mechanisms that underlie CNS involvement in SLE. Excellent reviews about other aspects of this and other murine models of lupus can be found elsewhere $[3,11,21-34]$.

1.1. Murine Models of NP-SLE. To best represent human disease and explore relevant translational aspects of pathogenesis and novel treatment approaches, it is crucial to identify the most appropriate animal model from among the several available mouse strains which spontaneously develop lupus-like disease. Although there are induced models of SLE in nonautoimmune mouse strains, organ involvement as a rule is less severe than that observed in genetically susceptible animals $[35,36]$. Therefore, spontaneous lupus models are often preferred for modeling of lupus-associated neuropsychiatric or other target organ disease. Murine models that spontaneously develop hallmark diagnostic signs of SLE include NZB $\times$ NZW F1, NZM2410, BXSB, and MRL/lpr mouse strains. All of these strains (to a varying degree) develop lymphoid hyperplasia, B cell hyperactivity, autoantibodies, circulating immune complexes, complement consumption, and glomerulonephritis [21]. These strains differ from human SLE in that they display a high penetrance and relatively uniform disease expression over time. However, the disease course in murine lupus models (in the absence of extraneous intervention) is progressive, in contrast to the fluctuating course of flares and remissions typical in human SLE $[26,27,37]$. Although many of the spontaneous models of SLE develop behavioral abnormalities at some point in the disease [27], the MRL mouse model has some advantages in the investigation of specific CNS dysfunction and NP-SLE.

First, NZB- and BXSB-derived strains of mice have a high incidence of inherited brain anomalies [38] which can confound the assessment of autoimmunity-induced brain damage and the links between lupus-like disease and behavioral changes. Thus the MRL/lpr model permits the examination of interrelationships between behavioral outcomes and their underlying mechanisms without the potential confound of pre-existing CNS abnormalities [3840]. As human SLE is overwhelmingly more common in females (about a 9:1 female to male ratio), mouse models that reflect this sex bias, such as MRL/lpr [14], are also likely to be useful in elucidating the relationship of hormones, negative outcomes, and potential sex-differences in efficacy of therapeutic agents in autoimmune disease. MRL/lpr mice [41] also express cardiolipin autoantibodies [42], one of a class of antiphospholipid autoantibodies thought to be important in the development of behavioral outcomes and CNS damage [43-45]. Although the molecular defect in the Fas gene underlying abnormal B cell regulation in MRL/lpr mice is not believed to be a cause for human SLE $[46,47]$, it is clear that the B cell dysregulation that characterizes this murine model is also a critical pathological aspect of human SLE $[48,49]$. Moreover, the early onset, rapid progression, and other similarities to the human disease state in MRL/lpr mice are also useful features of this model.

The MRL lymphoproliferation strain (lpr) MRL/Tnfrsf6 lpr/lpr (a.k.a. MRL/lpr) differs from the congenic (control) $\mathrm{MRL} /+$ strain by a defect in membrane apoptoticsignaling Fas protein, which is due to a retrotransposon in the Fas gene $[50,51]$. In addition to the typical signs of peripheral SLE, including autoantibodies, skin disease, arthritis, lymphadenopathy, and nephritis, MRL/lpr mice develop a constellation of behavioral outcomes referred to as "autoimmunity-associated behavioral syndrome" [24], particularly in the behavioral domains of emotional reactivity, motivated behavior, and cognitive function $[14,20,22,24$, 33, 52-75].

1.2. NP-SLE. Nervous system involvement in lupus can include seizures, stroke and other cerebrovascular events, psychosis, cognitive dysfunction, and notably a very high incidence of mood disorders, particularly anxiety and depression [2, 18, 76-78]. Estimations of the prevalence of NP-SLE in human lupus range from $15 \%$ to $75 \%$ (or higher), reflecting variable diagnostic methodologies, a lack of standard criteria, and the sensitivity of diagnostic instruments to assess various behavioral outcomes $[1,2,79]$. Furthermore, many clinical studies of NP-SLE address only the most severe CNS symptoms, such as seizure, psychosis, and stroke, thus both the prevalence and importance of other neuropsychiatric symptoms are often underestimated. Generally, when specific and well-validated cognitive and affective diagnostic batteries are administered, rather than simple quality of life exams, studies consistently indicate that a great majority of SLE patients have some CNS outcomes, particularly mood disorders and cognitive dysfunction. NPSLE is a major determinant of morbidity and mortality and is associated with increased disease severity, poorer prognosis and earlier mortality [80-85]. Furthermore, NP-SLE can necessitate potent and long-term immunosuppressive treatment with attendant side effects, is a detriment to quality of life in lupus patients, may be a major factor in employment disability, and substantially increases the financial and emotional costs of SLE $[86,87]$. Comprehensive reviews of NPSLE manifestations, diagnosis, pathology, and treatment in humans are outside the scope of the paper, and can be found elsewhere [2, 4, 9, 88-94].

1.3. Neuropsychiatric Deficits in MRL/lpr Mice. As in humans, development of SLE in MRL/lpr mice is also consistently accompanied by behavioral and neurological abnormalities. The most robust and reproducible deficits in MRL/lpr mice are emotional dysfunction, particularly in assays of depressive-like behavior such as the forced swim test and anhedonia. The forced swim test $[95,96]$ assesses behavioral despair as the proportion of immobility when rodents are placed in a tank of water $[97,98]$. Normal rodents placed in a narrow tank of water from which there is no escape will exhibit vigorous swimming and struggling activity for the duration of the test (typically 6-12 minutes) and only rarely adopt a characteristic immobile posture (floating). 
In contrast, animals treated with either pharmacological agents (such as hormones or via depletion of the amino acid tryptophan necessary to make serotonin $[99,100]$ ), environmental manipulations (unpredictable chronic stress, social isolation [101-103]), or genetic alterations (Flinders strain, SERT knockouts $[104,105]$ ) thought to be important in the etiology of depression more rapidly become immobile and maintain this immobility for a significantly great proportion of time than control subjects [106]. This is thought to represent "behavioral despair" or helplessness. The forced swim test has been extensively validated, as immobility is reduced by a wide range of clinically active antidepressant drugs [98] and has predicted the antidepressant efficacy of novel therapeutic agents [97]. MRL/lpr mice develop depression-like behavior in the forced swim test as early as 5 weeks old, and this persists throughout the course of the disease $[14,20,58,65]$.

In addition to feelings of helplessness and despair, depressed patients report anhedonia-the inability to experience pleasure or reward from events that normally have a positive hedonic value, such as eating, social interaction, or sexual activity. In rodents, a commonly used measure of anhedonia is the failure to prefer sweet solutions [107, 108]. MRL/lpr mice exhibit this lack of normal preference for sweet solutions as early as 5-6 weeks old [59] and continue to exhibit anhedonia during the active disease phase (45 months old) [52, 53, 55, 109]. Further symptoms of depression-like behavior include decreased activity, fatigue, and apathy. In rodents, this can be assessed as decreased voluntary activity and exploration in a novel environment, such as an open field [110]. MRL/lpr mice exhibit reduced exploration and activity during both the nocturnal and diurnal phases $[63,65]$ by $8-11$ weeks old $[14,33]$.

Despite the high prevalence of depression in lupus patients and recent evidence that antidepressants may reduce symptoms of depression, in part, by reducing inflammatory responses [111, 112], there have been few studies investigating the efficacy of antidepressant therapies in human lupus [113] or in murine models [58]. Immunosuppressive agents typically used to treat SLE, such as cyclophosphamide and steroids, do reduce measures of depression-like behavior in MRL/lpr mice $[33,55,59,114]$ and also typically reduce the other hallmarks of SLE, including autoantibody titers, proteinuria (nephritis), and the levels of proinflammatory cytokines $[55,59]$. However, there have been few systematic studies to determine if these are effective at reducing measures of NP-SLE, especially cognitive and affective dysfunction, in humans. Several studies indicate that high levels of both affective and cognitive disorders are present and persistent in NP-SLE patients undergoing such therapies $[115,116]$, though these traditional immunosuppressive agents do seem to be effective to prevent and/or treat the more severe NP-SLE outcomes, such as seizure and cerebrovascular events $[13,117,118]$.

Anxiety disorders are also common in NP-SLE [1, 119] and are often comorbid with depressive disorders. Several commonly used methods can be applied to assess anxiety in rodents, and these include the elevated plus maze and the acoustic startle test [120-127]. The elevated plus maze (EPM) essentially assesses a preference between a comparatively safe environment (the closed arms) and a risky environment (elevated open spaces). The general principle is that the more "anxious" the subjects are, the less likely they will be to explore the open arms. The EPM has been validated pharmacologically, with other tests of anxiety-like behaviors, and physiologically [120-123]. With respect to anxiety in murine models of lupus, there have been conflicting reports. Some groups have reported increased anxiety in MRL/lpr mice assessed in the elevated plus maze [65], while others have reported that MRL/lpr mice have normal or less anxiety than MRL/+ controls $[14,20,70]$. The lack of anxiety phenotype is also supported by a generally lower startle reactivity till 11 weeks old [70].

There is also no clear consensus with respect to cognitive dysfunction in murine models of lupus. Mild spatial memory deficits have been reported in the water maze, assessed as the latency to find a new platform position after previous training in the water maze [63] and as deficits in linear maze acquisition as early as 8 weeks [68]. However, behavior in the object placement and novel object recognition tasks [128$130]$ is normal $[14,20]$.

The predominance and reproducibility of affective dysfunction in MRL/lpr mice are consistent with known pathology and/or dysfunction in several neurotransmitter systems and brain regions important in the regulation of mood [131]. These include altered responses to the dopaminergic drugs amphetamine and apomorphine $[52,109,132]$ and higher levels of apoptosis in the dopaminergic neurons in the nucleus accumbens and substantia nigra (thought to be involved in response to reward and anhedonia) in MRL/lpr mice $[52,109]$. There are also decreased levels of serotonin in brain regions such as the hypothalamus, which regulate stress and response to appetitive stimuli (among other things) [133], and increased levels in the hippocampus [58]. This observation is consistent with altered serotonin levels in lupus patients similar to those that occur in depressed patients [134-136], including those in which depression has been induced by cytokine therapy [137-139]. Decreased levels of noradrenaline evident in the prefrontal cortex of MRL/lpr mice would also be consistent with depressive-like behavior [58, 140-142].

1.4. Comparison of More and Less Affected Lines. There is also a fascinating "accidental" experimental difference in MRL/lpr mice. Over time, this strain of mice displayed a lessening of symptoms such as lymphoproliferation, a greatly delayed development of nephritis, and a longer lifespan. The line was eventually reconstituted and again manifests rapid development of the typical severe autoimmune profile (http://jaxmice.jax.org/: re-coding of stock \#485attenuated disease to stock \#6825-reconstituted severe line). This serendipitous circumstance permits the differentiation between negative behavioral outcomes that may result from gross peripheral pathology and specific CNS-mediated behaviors $[14,143]$.

A major difference in the disease-attenuated line is the long delay to develop renal disease and profoundly decreased 
proteinuria $[14,20]$. The levels of autoantibodies tend to increase earlier and to a greater extent in the reconstituted severe line. Furthermore, the disease-attenuated line has normal open field activity from 8 to 18 weeks [20] while in the reconstituted severe line, the females have lower activity levels from 5 weeks, although MRL/lpr males exhibit normal open field activity until at least 18 weeks old $[14,20]$. Cognitive functions assessed in novel object exploration and placement tasks were normal in mice 5-18 weeks old in both sexes and both lines [14, 20]. Motor coordination in the balance beam and anxiety in the elevated plus maze were also comparable in both lines from 5 to 18 weeks old $[14,20]$. Interestingly, there was no evidence of social withdrawal assessed in the social preference test [144] in either line from 5 to 18 weeks compared to age- and sex-matched controls [14, 20]. However these results were likely due to the very low social preference evident in both MRL/+ female controls and female MRL/lpr mice [20]. It is thus not clear if social withdrawal, a typical symptom of affective disorders, is evident in the MRL/lpr females due to SLE or if there is some influence of the background strain that induces social withdrawal by some other route in females.

Depression-like behavior is robustly evident in diseaseattenuated line in the forced swim test by 8 weeks [20] and in reconstituted severe line by 5 weeks [14], although earlier time points were not tested in the disease-attenuated line. Given that there is no evidence of kidney pathology in the disease-attenuated mice, these data confirm the robustness of emotional dysfunction and provide further support that such outcomes are likely a primary manifestation of autoimmunity rather than arising from nonspecific illness and peripheral organ pathology. Finally, the presence of two MRL/lpr strains that share a mutated Fas yet which differ in their autoantibody profile and neurobehavioral manifestations $[14,143]$ is strong evidence that the CNS manifestations in these mice are primarily immunologically mediated, rather than resulting from possible effects of abnormal Fas-mediated apoptosis on brain development or glial function.

\section{CNS Mechanisms and Pathology}

Several different pathogenic mechanisms are postulated to be involved in CNS manifestations of lupus. These include B cell/autoantibody-mediated nervous system compromise, immune complex deposition, vasculitis, microthrombosis and vasculopathy, aberrant MHC Class II antigen expression with T-cell mediated disease, autoactivated T-cells, and cytokine-induced brain inflammation $[145,146]$. However, as there are multiple and quite disparate expressions of lupus involving the nervous system, it is unlikely that a single mechanism can account for every clinical manifestation of NP-SLE. As the most common behavioral manifestations of NP-SLE in both patients and murine models are affective and cognitive disorders, especially in the early stages of SLE, we focus on below mechanisms thought to be involved in the etiology of affective and cognitive dysfunction.
2.1. Autoantibodies. MRL/lpr mice express a range of autoantibodies [147] including antinucleosome [148], antiribosomal [149] antiphospholipid, and phosphoprotein (such as anticardiolipin [42] and antinucleolin) [150] autoantibodies [151]. A critical role of autoantibodies in the etiology of lupus-associated nephritis has been well documented. Nephritogenic lupus autoantibodies initiate immune deposit formation through direct or indirect interaction with glomerular antigens $[152,153]$ and result in kidney pathology that can be prevented by administration of an immunoglobulinbinding peptide $[151,154]$. It has been suggested that autoantibodies reacting with brain antigens may similarly play a role in CNS pathology and negative behavioral outcomes in NP-SLE $[90,155]$.

Evidence supporting the role of autoantibodies in the pathogenesis of NP-SLE includes the increased titer of autoantibodies in serum of diseased MRL/lpr mice [156$158]$, which occurs earlier in females [156, 159], consistent with the earlier onset of depressive-like behavior in MRL/lpr females [14]. There is also evidence that some of these serum autoantibodies react with brain antigens $[160,161]$ and occur in serum of as early as 2-3 months old in MRL/lpr mice [61] and in CSF as early as 4-5 months [162]. Nevertheless, as further discussed below, the fact that behavioral deficits are present before major rises in serum autoantibody titers or detectable breaches in the blood-brain barrier indicates that serum antibodies alone are clearly not the sole important pathogenic factor in NP-SLE, at least early in the disease.

The relationship of serum and CSF levels of autoantibodies to the disease process is complex, but it is likely that intrathecal autoantibodies are likely to be more critically related to NP-SLE than are serum autoantibody titers. Some evidence does suggest a role for serum autoantibody levels in NP-SLE, as mice with more severe peripheral and behavioral manifestations of SLE also have more pronounced changes in hippocampal and cortical morphology and increased indices of cell death [163-166]. This can be prevented with doses of cyclophosphamide that reduce serum autoantibody titers [165], although CSF levels of autoantibodies were not assessed. However, IgG levels in serum, but not CSF, are positively correlated with spleen weight, suggesting that central autoimmune processes are relatively independent from systemic manifestations [167]. This is supported by the fact that the patterns of autoantibody expression in serum and CSF is not correlated over time in patients with NP-SLE [168]. Finally, CSF from diseased MRL/lpr mice which was treated to remove cytokines is cytotoxic to cultured cells [71, 169] and was more cytotoxic than serum derived from diseased animals [71], indicating a primary intrathecal source of cytotoxic autoantibodies. Cytotoxicity in culture was correlated with the extent of apoptosis in the brains of aged LPR mice from which the CSF was derived, thus toxic mediators produced by the CNS of diseased MRL/lpr mice are likely to be more pathogenic than those in serum. Therefore autoantibodies recognizing brain antigens are plausible candidates as neurotoxic moieties. The site of production of brain reactive antibodies in MRL-lpr mice is however not conclusively identified, although this remains a subject of intense research interest [162]. 
Autoantibodies recognizing brain antigens, such as the NMDA receptor subtype of the excitatory neurotransmitter, glutamate, are also present in the serum and CSF of patients with NP-SLE $[168,170]$. When injected directly into the brain of otherwise healthy mice, or when injected peripherally to animals with a compromised blood-brain barrier, these are neurotoxic and result in impaired cognition and emotional behavior [171-173]. In addition, intrathecal administration of antiribosomal $\mathrm{P}$ antibodies induces depression-like behavior in the forced swim test [174]. There have also been reports of positive correlations between serum levels of brain reactive autoantibodies and cognitive dysfunction and depression-like behavior $[90,155,175]$ although other studies have failed to find such relationships $[61,161,176]$ in patients with NP-SLE. It has thus been suggested that CSF levels of brain-reactive autoantibodies may be more important factors than serum titers to the genesis of NP-SLE pathology and symptoms [90, 177]. These data further support the notion that CNS-derived specific factors and possibly intrathecal production of autoantibodies can lead to brain pathology and corresponding negative behavioral outcomes $[52,162,169]$.

However, the blood-brain barrier restricts the influx of circulating factors, including lymphocytes and antibodies, from entering the brain and cerebral circulation. The brain also does not have resident antibody-producing cells. Generally, influx of antibodies or lymphocytes requires disintegration of the blood-brain barrier as general or localized lesions [27]. There is no convincing evidence to date that this occurs as early as the earliest manifestations of the negative behavioral outcomes. Therefore, while it is probable that the loss of integrity of the blood-brain barrier eventually occurs and obviously plays role in the resulting CNS pathology $[9,178-181]$, possibly in part by permitting the entry of autoantibodies and antibody-producing cells, negative behavioral outcomes might rather be initiated by different mechanisms than those that regulate pathology in peripheral organs and later onset, more severe symptoms of NP-SLE. Thus, autoantibodies are possibly not the sole or primarily etiology of several of the symptoms of NP-SLE, especially given the notable role of cytokines and chemokines in affective and cognitive disorders [182-186].

Indeed, several lines of evidence suggest that autoantibodies may not be sufficient to induce NP-SLE in the MRL/lpr strain. First, increased secretion of chemokines and cytokines (such as interferons) cause inflammatory pathology in kidney $[187,188]$, even in the absence of autoantibody deposits [189]. Furthermore, the high proinflammatory cytokine levels in MRL/lpr mice are progressive and correlated with increasing disease severity [190]. Conversely, antiinflammatory cytokine therapy is beneficial [191]. In fact, numerous anti-inflammatory agents with a wide variety of underlying mechanisms of action increase survival, reduce peripheral organ pathology, and normalize T-cell phenotypes in mice without altering the level of autoantibodies [192-197]. However, neuropsychiatric symptoms have not been systematically assessed in most of these studies so it is not clear if there are also similar benefits to behavioral outcomes. Further evidence suggesting that autoantibodies are not sufficient to produce NP-SLE includes the fact that DNA-binding antibodies derived from autoimmune MRL mice fail to induce SLE-like changes when administered to healthy animals [198]. Actually, all strains of mice thus far tested show some brain reactive autoantibodies in serum [199] even in the absence of abnormal behavior. Last, MRL/lpr mice that express a mutant transgene that prevents the secretion of circulating IgG still develop nephritis despite the lack of soluble autoantibody production, indicating that circulating autoantibodies are neither requisite nor sufficient to induce pathology [200].

Thus, serum antibodies could be neurotoxic, but they can only access brain tissue after a compromise of bloodbrain barrier integrity. Lymphocytes can also not access the brain through an intact blood-brain barrier. Furthermore, insults to the blood-brain barrier are likely to be regional rather than global and may occur later in the disease than the onset of robust emotional disturbances. So if brain-reactive autoantibodies are not engendering such symptoms early in NP-SLE, then what is?

2.2. Chemokines and Cytokines. Cytokines and chemokines are likely to be critical early factors regulating the negative behavioral outcomes, as they need not pass the bloodbrain barrier to regulate neural function [57, 183, 201]. Detection of increased secretion of peripheral inflammatory cytokines can occur across an intact blood-brain barrier, in part via the vagus nerve. This induces glia and microglia to produce cytokines and other inflammatory and cytotoxic agents (including prostaglandins and nitric oxide). These are well documented to elicit the physiological and behavioral symptoms of mood disorders, including lethargy, decreased social interaction, immobility in the forced swim test, and anhedonia $[183,184,202-204]$. Finally, cytokines have been linked to depression in humans [205-213] and to neuropsychiatric symptoms in NP-SLE patients $[8,12,170$, $185,214,215]$.

The role of cytokines in emotional disturbances in MRL/lpr mice is supported by numerous studies. In very large samples, the severity of behavioral deficits in MRL/lpr mice does not relate strictly to autoantibody titers or brain infiltration by $\mathrm{T}$ cells [57], which would indicate a compromised blood-brain barrier. Cytokine, chemokine, and prostaglandin dysregulation occurs as early as $1-4$ weeks in MRL/lpr mice, well before disease onset and upregulation of autoantibodies [26, 30, 216-223].

Clinically, cytokine-mediated depression has certainly resulted from cytokine administration when used as treatments in cancer and viral infections [224-228]. Increased levels of IL-6 and other cytokines have been found in the cerebrospinal fluid and brains of patients with NP-SLE [229]. In MRL/lpr mice, treatment with anti-inflammatory cytokines reduces disease severity [189, 230-237] while administration of proinflammatory cytokines accelerates glomerulonephritis, vasculitis, and other disease manifestations [231, 233]. MRL/lpr mice lacking the IL-6 receptor have delayed mortality and nephritis and a reduction of autoantibody complex deposition [238], though these mice 
have not been behaviorally tested, so the affect on symptoms of NP-SLE is not known.

The early dysregulation of cytokine production, especially TNF-alpha, IL-1, IL-2, and IL-6 [188, 223, 239, $240]$, corresponds to the onset of symptoms of depressivelike behavior, such as anhedonia and behavioral despair in MRL/lpr mice [59] and in other rodent strains [241, 242]. Anhedonia can be ameliorated by cyclophosphamide, which abolishes the typically early and significant rise of cytokines, particularly IL-6 [59]. Notably, anhedonia and other behavioral indices of depressive-like behavior in mice can be replicated by exogenous IL-6 [59] and are prevented by knockout of the IL-6 receptor [203]. Other proinflammatory immunomodulators, such as TNF-alpha, also increase behavioral indices of depressive-like behavior in mice [243] while blocking their secretion or receptors decreases depressive-like behavior [242, 243]. High levels of proinflammatory cytokines may also impair the function of the blood-brain barrier [244, 245] and may thus be permissive to the negative effects of autoantibodies and lymphocytes. Finally, cytokine dysregulation is a shared characteristic of murine lupus models with different underlying genetic mechanisms [246].

Thus, while recent and substantial evidence indicates a role for cytokines in the early mechanisms of NP-SLE, several obstacles have prevented the further studies needed to elucidate the specific underlying etiology. First, it is important to recognize that local alterations in brain cytokine levels that can be very relevant to NP-SLE pathogenesis may be present early in the disease course, yet these may not necessarily be reflected in abnormal serum levels. Second, there are numerous cytokines, and it is a gross oversimplification to assume that an individual cytokine is pro- or anti-inflammatory. Rather, the precise proportions of cytokine levels in serum and brain are likely to be more important than absolute levels of a single cytokine. However, comprehensive analysis of multiple cytokines is prohibitively expensive. Furthermore, cytokines are necessary for normal brain development and cognitive function [247-250], and thus global knock-outs of specific cytokine receptors can be problematic, as these can cause cognitive, reproductive, and other deficits $[248,251]$ and also require large breeding colonies to achieve appropriate genotypes. More precise timing of cytokine receptor knockdown can be accomplished by viral vectors, but these are also less than ideal in studies of SLE as they are thought to induce immune responses [252]. Other methods of receptor knockdown that are more promising include siRNA.

\section{Sex Differences}

There is a much higher incidence of SLE in females than in males. Moreover, females with autoimmune disease have a higher risk of psychiatric disorders, particularly depression [80]. Disease severity and rate of progression are also accelerated in female MRL/lpr mice as compared to males of this strain. Serum autoantibodies appear earlier in female MRL/lpr mice $[14,156]$. Female MRL/lpr mice also have higher levels of IgG in the CSF compared to males [253]. Symptoms of depressive-like behavior are also worse in female MRL/lpr mice [14].

One possible mediator of sex differences in the prevalence and outcomes of SLE is sex steroid hormones, such as estrogens [254-263]. Administration of exogenous estrogens can induce a lupus-like syndrome in otherwise healthy mice [258] and exacerbate symptoms in MRL/lpr mice, in which estrogens globally increase IgM levels [264] autoantibody titers [156], glomerulonephritis, lymphoproliferation, mortality [257], and cytokine levels [265]. Conversely, treatment with the estrogen receptor antagonist, tamoxifen, reduces proteinuria, serum tiers of anti-dsDNA autoantibodies and increases survival [266]. Estrogens also differentially affect $\mathrm{B}$ and $\mathrm{T}$ cell-mediated immune responses in MRL/lpr mice $[255,256]$. Immune complex-mediated glomerulonephritis is significantly accelerated by estrogens whereas $\mathrm{T}$ cellmediated lesions, such as renal vasculitis and periarticular inflammation, are reduced in MRL/lpr mice after estrogen treatment $[255,256]$. Estrogens can also modulate bloodbrain barrier permeability $[267,268]$ and increase cytokine levels in patients with SLE $[259,262,269,270]$. Moreover, the myriad effects of estrogen on neuroprotection are being increasingly recognized [271-273]. While space constraints prevent going into further details about the role of sex hormones in maintaining the integrity of the blood-brain barrier and providing neuroprotection, the interested reader can find additional details in some recent comprehensive reviews [267, 271, 272, 274, 275]. These sex and hormone differences may have clinical implications for treatment of SLE, as cyclophosphamide prevents pulmonary disease in male but not female MRL/lpr mice [276]. Similarly, sex differences in the efficacy of treatment in autoimmune disorders is not uncommon [277]. Furthermore, there are notable sex differences in both humans and in animal models in the susceptibility of depression, responses to antidepressant treatments, and in underlying hormonal, immune, and neurochemical alterations in affective disorders $[278,279]$.

\section{Conclusion}

CNS disease in NP-SLE may share common mechanisms with peripheral organ pathology in SLE, especially in the latter stages of the disease, but the distinct nature of CNSmediated immunity and the blood-brain barrier indicates that early manifestations of particularly mood disorders may be derived from some unique mechanisms. Additionally, agents critical to the pathology of NP-SLE, such as cytokines, are regulated by sex and steroid hormones, which is consistent with the predominance of SLE and mood disorders in females. Altered cytokine profiles in serum and/or CNS can result in the activation of astrocytes, microglia, and changes in neuronal function and morphology and dysregulation of the blood-brain barrier. Pathology of the blood-brain barrier could lead to altered homeostasis and play a significant role in impairment of CNS function seen in later onset of NP-SLE as well many other immune disorders. 
Despite the importance of the MRL/lpr and other murine models for elucidating the underlying mechanisms of NPSLE, there are yet many questions that have not been conclusively answered. These include relating measures of the earliest onset of negative behavioral outcomes with intrathecal levels of cytokines and native brain-reactive autoantibodies, systematic study of the efficacy of alternative therapeutics (such as traditional and novel antidepressants), and comprehensive analysis of the time course of bloodbrain barrier dysfunction.

\section{References}

[1] R. L. Brey, S. L. Holliday, A. R. Saklad et al., "Neuropsychiatric syndromes in lupus: prevalence using standardized definitions," Neurology, vol. 58, no. 8, pp. 1214-1220, 2002.

[2] H. Ainiala, J. Loukkola, J. Peltola, M. Korpela, and A. Hietaharju, "The prevalence of neuropsychiatric syndromes in systemic lupus erythematosus," Neurology, vol. 57, no. 3, pp. 496-500, 2001.

[3] D. A. Ballok, "Neuroimmunopathology in a murine model of neuropsychiatric lupus," Brain Research Reviews, vol. 54, no. 1, pp. 67-79, 2007.

[4] A. T. Borchers, C. A. Aoki, S. M. Naguwa, C. L. Keen, Y. Shoenfeld, and M. E. Gershwin, "Neuropsychiatric features of systemic lupus erythematosus," Autoimmunity Reviews, vol. 4, no. 6, pp. 329-344, 2005.

[5] T. Colasanti, F. Delunardo, P. Margutti et al., "Autoantibodies involved in neuropsychiatric manifestations associated with systemic lupus erythematosus," Journal of Neuroimmunology, vol. 212, no. 1-2, pp. 3-9, 2009.

[6] S. D. Denburg, R. M. Carbotte, and J. A. Denburg, "Cognitive impairment in systemic lupus erythematosus: a neuropsychological study of individual and group deficits," Journal of Clinical and Experimental Neuropsychology, vol. 9, no. 4, pp. 323-339, 1987.

[7] J. G. Hanly, J. D. Fisk, G. Sherwood, E. Jones, J. V. Jones, and B. Eastwood, "Cognitive impairment in patients with systemic lupus erythematosus," Journal of Rheumatology, vol. 19, no. 4, pp. 562-567, 1992.

[8] X. Y. Lu, C. Q. Zhu, J. Qian, X. X. Chen, S. Ye, and Y. $\mathrm{Y}$. $\mathrm{Gu}$, "Intrathecal cytokine and chemokine profiling in neuropsychiatric lupus or lupus complicated with central nervous system infection," Lupus, vol. 19, no. 6, pp. 689-695, 2010.

[9] N. J. Abbott, L. L. F. Mendonça, and D. E. M. Dolman, "The blood-brain barrier in systemic lupus erythematosus," Lupus, vol. 12, no. 12, pp. 908-915, 2003.

[10] E. Trysberg, H. Carlsten, and A. Tarkowski, "Intrathecal cytokines in systemic lupus erythematosus with central nervous system involvement," Lupus, vol. 9, no. 7, pp. 498503, 2000.

[11] M. Tomita, R. L. Khan, B. H. Blehm, and T. J. Santoro, "The potential pathogenetic link between peripheral immune activation and the central innate immune response in neuropsychiatric systemic lupus erythematosus," Medical Hypotheses, vol. 62, no. 3, pp. 325-335, 2004.

[12] H. Fragoso-Loyo, Y. Richaud-Patin, A. Orozco-Narvaez et al., "Interleukin-6 and chemokines in the neuropsychiatric manifestations of systemic lupus erythematosus," Arthritis and Rheumatism, vol. 56, no. 4, pp. 1242-1250, 2007.
[13] N. Kasitanon, W. Louthrenoo, S. Piyasirisilp, W. Sukitawut, and R. Wichainun, "Neuropsychiatric manifestations in thai patients with systemic lupus erythematosus," Asian Pacific Journal of Allergy and Immunology, vol. 20, no. 3, pp. 179$185,2002$.

[14] H.-X. Gao, E. Sanders, A. T. Tieng, and C. Putterman, "Sex and autoantibody titers determine the development of neuropsychiatric manifestations in lupus-prone mice," Journal of Neuroimmunology, vol. 229, no. 1-2, pp. 112-122, 2010.

[15] A. P. Van Dam, "Diagnosis and pathogenesis of CNS lupus," Rheumatology International, vol. 11, no. 1, pp. 1-11, 1991.

[16] E. J. Feinglass, F. C. Arnett, C. A. Dorsch, T. M. Zizic, and M. B. Stevens, "Neuropsychiatric manifestation of systemic lupus erythematosus: diagnosis, clinical spectrum, and relationship to other features of the disease," Medicine, vol. 55, no. 4, pp. 323-339, 1976.

[17] R. M. Carbotte, S. D. Denburg, and J. A. Denburg, "Cognitive dysfunction in systemic lupus erythematosus is independent of active disease," Journal of Rheumatology, vol. 22, no. 5, pp. 863-867, 1995.

[18] T. Olsen Utset, M. Golden, G. Siberry, N. Kiri, R. M. Crum, and M. Petri, "Depressive symptoms in patients with systemic lupus erythematosus: association with central nervous system lupus and Sjogren's syndrome," Journal of Rheumatology, vol. 21, no. 11, pp. 2039-2045, 1994.

[19] Y. Shimojima, M. Matsuda, T. Gono, W. Ishii, and S. I. Ikeda, "Relationship between clinical factors and neuropsychiatric manifestations in systemic lupus erythematosus," Clinical Rheumatology, vol. 24, no. 5, pp. 469-475, 2005.

[20] H. X. Gao, S. R. Campbell, M. H. Cui et al., "Depression is an early disease manifestation in lupus-prone MRL/lpr mice," Journal of Neuroimmunology, vol. 207, no. 1-2, pp. 45-56, 2009.

[21] B. Andrews, R. A. Eisenberg, A. N. Theofilopoulos et al., "Spontaneous murine lupus-like syndromes. Clinical and immunopathological manifestations in several strains," Journal of Experimental Medicine, vol. 148, no. 5, pp. 11981215, 1978.

[22] R. L. Brey, B. Sakic, H. Szechtman, and J. A. Denburg, "Animal models for nervous system disease in systemic lupus erythematosus," Annals of the New York Academy of Sciences, vol. 823, pp. 97-106, 1997.

[23] S. L. Peng and J. Craft, "The regulation of murine lupus," Annals of the New York Academy of Sciences, vol. 815, pp. 128138, 1997.

[24] B. Sakic, H. Szechtivian, and J. A. Denburg, "Neurobehavioral alterations in autoimmune mice," Neuroscience and Biobehavioral Reviews, vol. 21, no. 3, pp. 327-340, 1997.

[25] N. Shanks, P. M. Moore, P. Perks, and S. L. Lightman, "Endocrine correlates of murine systemic lupus erythematosus in the MRL lpr/lpr model," Annals of the New York Academy of Sciences, vol. 823, pp. 252-255, 1997.

[26] A. N. Theofilopoulos and F. J. Dixon, "Murine models of systemic lupus erythematosus," Advances in Immunology, vol. 37, pp. 269-390, 1985.

[27] J. J. Alexander and R. J. Quigg, "Systemic lupus erythematosus and the brain: what mice are telling us," Neurochemistry International, vol. 50, no. 1, pp. 5-11, 2007.

[28] J. F. Bach, "Cytokine-based immunomodulation of autoimmune diseases: an overview," Transplantation Proceedings, vol. 28, no. 6, pp. 3023-3025, 1996.

[29] J. A. Denburg, B. Sakic, H. Szechtman, S. D. Denburg, B. Itsvan, and M. G. Reginald, "Lupus as a model of 
neuroimmune interactions," NeuroImmune Biology, vol. 1, pp. 379-386, 2001.

[30] D. Hartwell, J. Levine, M. Fenton, C. Francis, C. Leslie, and D. Beller, "Cytokine dysregulation and the initiation of systemic autoimmunity," Immunology Letters, vol. 43, no. 1-2, pp. 1521, 1994.

[31] J. Itoh, S. Takahashi, M. Ono, T. Yamamoto, M. Nose, and M. Kyogoku, "Nephritogenic antibodies in MRL/lpr lupus mice: molecular characteristics in pathological and genetic aspects," Tohoku Journal of Experimental Medicine, vol. 173, no. 1, pp. 65-74, 1994.

[32] V. R. Kelley and R. P. Wüthrich, "Cytokines in the pathogenesis of systemic lupus erythematosus," Seminars in Nephrology, vol. 19, no. 1, pp. 57-66, 1999.

[33] H. Szechtman, B. Sakic, and J. A. Denburg, "Behaviour of MRL mice: an animal model of disturbed behaviour in systemic autoimmune disease," Lupus, vol. 6, no. 3, pp. 223229, 1997.

[34] B. Diamond and B. Volpe, "On the track of neuropsychiatric lupus," Arthritis and Rheumatism, vol. 48, no. 10, pp. 27102712, 2003.

[35] W. H. Reeves, P. Y. Lee, J. S. Weinstein, M. Satoh, and L. Lu, "Induction of autoimmunity by pristane and other naturally occurring hydrocarbons," Trends in Immunology, vol. 30, no. 9, pp. 455-464, 2009.

[36] B. Deocharan, X. Qing, E. Beger, and C. Putterman, "Antigenic triggers and molecular targets for anti-double-stranded DNA antibodies," Lupus, vol. 11, no. 12, pp. 865-871, 2002.

[37] A. N. Theofilopoulos, R. Kofler, P. A. Singer, and F. J. Dixon, "Molecular genetics of murine lupus models," Advances in Immunology, vol. 46, pp. 61-109, 1989.

[38] G. F. Sherman, L. Morrison, G. D. Rosen, P. O. Behan, and A. M. Galaburda, "Brain abnormalities in immune defective mice," Brain Research, vol. 532, no. 1-2, pp. 25-33, 1990.

[39] G. F. Sherman, J. S. Stone, D. M. Press, G. D. Rosen, and A. M. Galaburda, "Abnormal architecture and connections disclosed by neurofilament staining in the cerebral cortex of autoimmune mice," Brain Research, vol. 529, no. 1-2, pp. 202-207, 1990.

[40] G. D. Rosen, G. F. Sherman, K. Emsbo, C. Mehler, and A. M. Galaburda, "The midsagittal area of the corpus callosum and total neocortical volume differ in three inbred strains of mice," Experimental Neurology, vol. 107, no. 3, pp. 271-276, 1990.

[41] E. L. Alexander, E. D. Murphy, J. B. Roths, and G. E. Alexander, "Congenic autoimmune murine models of central nervous system disease in connective tissue disorders," Annals of Neurology, vol. 14, no. 2, pp. 242-248, 1983.

[42] A. E. Gharavi, R. C. Mellors, and K. B. Elkon, "IgG anti-cardiolipin antibodies in murine lupus," Clinical and Experimental Immunology, vol. 78, no. 2, pp. 233-238, 1989.

[43] S. D. Denburg, R. M. Carbotte, J. S. Ginsberg, and J. A. Denburg, "The relationship of antiphospholipid antibodies to cognitive function in patients with systemic lupus erythematosus," Journal of the International Neuropsychological Society, vol. 3, no. 4, pp. 377-386, 1997.

[44] D. L. V. Greenwood, V. M. Gitlits, F. Alderuccio, J. W. Sentry, and B. H. Toh, "Autoantibodies in neuropsychiatric lupus," Autoimmunity, vol. 35, no. 2, pp. 79-86, 2002.

[45] A. Afeltra, P. Garzia, A. Paola Mitterhofer et al., "Neuropsychiatric lupus syndromes: relationship with antiphospholipid antibodies," Neurology, vol. 61, no. 1, pp. 108-110, 2003.
[46] C. E. Jackson and J. M. Puck, "Autoimmune lymphoproliferative syndrome, a disorder of apoptosis," Current Opinion in Pediatrics, vol. 11, no. 6, pp. 521-527, 1999.

[47] J. Drappa, A. K. Vaishnaw, K. E. Sullivan, J. L. Chu, and K. B. Elkon, "Fas gene mutations in the Canale-Smith syndrome, an inherited lymphoproliferative disorder associated with autoimmunity," New England Journal of Medicine, vol. 335, no. 22, pp. 1643-1649, 1996.

[48] O. T. M. Chan, M. P. Madaio, and M. J. Shlomchik, "The central and multiple roles of B cells in lupus pathogenesis," Immunological Reviews, vol. 169, pp. 107-121, 1999.

[49] I. Sanz and F. E. H. Lee, "B cells as therapeutic targets in SLE," Nature Reviews Rheumatology, vol. 6, no. 6, pp. 326337, 2010.

[50] M. Adachi, R. Watanabe-Fukunaga, and S. Nagata, "Aberrant transcription caused by the insertion of an early transposable element in an intron of the Fas antigen gene of lpr mice," Proceedings of the National Academy of Sciences of the United States of America, vol. 90, no. 5, pp. 1756-1760, 1993.

[51] F. J. Dixon, B. S. Andrews, R. A. Eisenberg, P. J. McConahey, A. N. Theofilopoulos, and C. B. Wilson, "Etiology and pathogenesis of a spontaneous lupus-like syndrome in mice," Arthritis and Rheumatism, vol. 21, pp. S64-S67, 1978.

[52] D. A. Ballok, A. M. Earls, C. Krasnik, S. A. Hoffman, and B. Sakic, "Autoimmune-induced damage of the midbrain dopaminergic system in lupus-prone mice," Journal of Neuroimmunology, vol. 152, no. 1-2, pp. 83-97, 2004.

[53] D. A. Ballok, H. Szechtman, and B. Sakic, "Taste responsiveness and diet preference in autoimmune MRL mice," Behavioural Brain Research, vol. 140, no. 1-2, pp. 119-130, 2003.

[54] N. Shanks, P. M. Moore, P. Perks, and S. L. Lightman, "Alterations in hypothalamic-pituitary-adrenal function correlated with the onset of murine SLE in MRL +/+ and lpr/lpr mice," Brain, Behavior, and Immunity, vol. 13, no. 4, pp. 348-360, 1999.

[55] B. Sakic, J. A. Denburg, S. D. Denburg, and H. Szechtman, "Blunted sensitivity to sucrose in autoimmune MRL-lpr mice: a curve-shift study," Brain Research Bulletin, vol. 41, no. 5, pp. 305-311, 1996.

[56] B. Sakic, L. Gurunlian, and S. D. Denburg, "Reduced aggressiveness and low testosterone levels in autoimmune MRL-lpr males," Physiology and Behavior, vol. 63, no. 2, pp. 305-309, 1998.

[57] B. Sakic, S. E. Hanna, and J. M. Millward, "Behavioral heterogeneity in an animal model of neuropsychiatric lupus," Biological Psychiatry, vol. 57, no. 6, pp. 679-687, 2005.

[58] B. Sakic, S. Lacosta, J. A. Denburg, and H. Szechtman, "Altered neurotransmission in brains of autoimmune mice: pharmacological and neurochemical evidence," Journal of Neuroimmunology, vol. 129, no. 1-2, pp. 84-96, 2002.

[59] B. Sakic, H. Szechtman, T. Braciak, C. Richards, J. Gauldie, and J. A. Denburg, "Reduced preference for sucrose in autoimmune mice: a possible role of interleukin-6," Brain Research Bulletin, vol. 44, no. 2, pp. 155-165, 1997.

[60] B. Sakic, H. Szechtman, S. Denburg, R. Carbotte, and J. A. Denburg, "Spatial learning during the course of autoimmune disease in MRL mice," Behavioural Brain Research, vol. 54, no. 1, pp. 57-66, 1993.

[61] B. Sakic, H. Szechtman, S. Denburg, R. Carbotte, and J. A. Denburg, "Brain-reactive antibodies and behavior of autoimmune MRL-lpr mice," Physiology and Behavior, vol. 54, no. 5, pp. 1025-1029, 1993. 
[62] B. Sakic, H. Szechtman, S. D. Denburg, and J. A. Denburg, "Immunosuppressive treatment prevents behavioral deficit in autoimmune MRL-lpr mice," Physiology and Behavior, vol. 58, no. 4, pp. 797-802, 1995.

[63] B. Sakic, H. Szechtman, M. Keffer, H. Talangbayan, R. Stead, and J. A. Denburg, "A behavioral profile of autoimmune lupus-prone MRL mice," Brain, Behavior, and Immunity, vol. 6, no. 3, pp. 265-285, 1992.

[64] B. Sakic, H. Szechtman, H. Talangbayan, S. Denburg, R. Carbotte, and J. A. Denburg, "Behavior and immune status of MRL mice in the postweaning period," Brain, Behavior, and Immunity, vol. 8, no. 1, pp. 1-13, 1994.

[65] B. Sakic, H. Szechtman, H. Talangbayan, S. D. Denburg, R. M. Carbotte, and J. A. Denburg, "Disturbed emotionality in autoimmune MRL-lpr mice," Physiology and Behavior, vol. 56, no. 3, pp. 609-617, 1994.

[66] J. M. Petitto, Z. Huang, J. Lo, R. D. Beck, C. Rinker, and D. A. Hartemink, "Relationship between the development of autoimmunity and sensorimotor gating in MRL-lpr mice with reduced IL-2 production," Neuroscience Letters, vol. 328, no. 3, pp. 304-308, 2002.

[67] S. Williams, B. Sakic, and S. A. Hoffman, "Circulating brainreactive autoantibodies and behavioral deficits in the MRL model of CNS lupus," Journal of Neuroimmunology, vol. 218, no. 1-2, pp. 73-82, 2010.

[68] C. M. Vogelweid, D. C. Wright, J. C. Johnson, J. E. Hewett, and S. E. Walker, "Evaluation of memory, learning ability, and clinical neurologic function in pathogen-free mice with systemic lupus erythematosus," Arthritis and Rheumatism, vol. 37, no. 6, pp. 889-897, 1994.

[69] M. Tomita, B. J. Holman, L. S. Williams, K. C. H. Pang, and T. J. Santoro, "Cerebellar dysfunction is associated with overexpression of proinflammatory cytokine genes in lupus," Journal of Neuroscience Research, vol. 64, no. 1, pp. 26-33, 2001.

[70] D. M. Nielsen and L. S. Crnic, "Elevated plus maze behavior, auditory startle response, and shock sensitivity in predisease and in early stage autoimmune disease MRL/lpr mice," Brain, Behavior, and Immunity, vol. 16, no. 1, pp. 46-61, 2002.

[71] D. Maric, J. M. Millward, D. A. Ballok et al., "Neurotoxic properties of cerebrospinal fluid from behaviorally impaired autoimmune mice," Brain Research, vol. 920, no. 1-2, pp. 183-193, 2001.

[72] O. Lechner, Y. Hu, M. Jafarian-Tehrani et al., "Disturbed immunoendocrine communication via the hypothalamopituitary-adrenal axis in murine lupus," Brain, Behavior, and Immunity, vol. 10, no. 4, pp. 337-350, 1996.

[73] Y. Hu, H. Dietrich, M. Herold, P. C. Heinriche, and G. Wick, "Disturbed immuno-endocrine communication via the hypothalamo-pituitary-adrenal axis in autoimmune disease," International Archives of Allergy and Immunology, vol. 102, no. 3, pp. 232-241, 1993.

[74] L. J. Grota, R. Ader, and N. Cohen, "Taste aversion learning in autoimmune MRL-lpr/lpr and $\mathrm{Mrl}+/+$ mice," Brain Behavior and Immunity, vol. 1, no. 3, pp. 238-250, 1987.

[75] L. J. Grota, T. R. Schachtman, J. A. Moynihan, N. Cohen, and R. Ader, "Voluntary consumption of cyclophosphamide by Mrl mice," Brain Behavior and Immunity, vol. 3, no. 3, pp. 263-273, 1989.

[76] G. Giovacchini, M. Mosca, G. Manca et al., "Cerebral blood flow in depressed patients with systemic lupus erythematosus," Journal of Rheumatology, vol. 37, no. 9, pp. 1844-1851, 2010.
[77] J. G. Hanly, J. D. Fisk, G. McCurdy, L. Fougere, and JO. A. Douglas, "Neuropsychiatric syndromes in patients with systemic lupus erythematosus and rheumatoid arthritis," Journal of Rheumatology, vol. 32, no. 8, pp. 1459-1466, 2005.

[78] E. Kozora, M. C. Ellison, and S. West, "Depression, fatigue, and pain in systemic lupus erythematosus (SLE): relationship to the American College of Rheumatology SLE neuropsychological battery," Arthritis Care and Research, vol. 55, no. 4, pp. 628-635, 2006.

[79] R. M. Carbotte, S. D. Denburg, and J. A. Denburg, "Prevalence of cognitive impairment in systemic lupus erythematosus," Journal of Nervous and Mental Disease, vol. 174, no. 6, pp. 357-364, 1986.

[80] K. Sundquist, X. Li, K. Hemminki, and J. Sundquist, "Subsequent risk of hospitalization for neuropsychiatric disorders in patients with rheumatic diseases: a nationwide study from Sweden," Archives of General Psychiatry, vol. 65, no. 5, pp. 501-507, 2008.

[81] H. E. Fragoso-Loyo and J. Sánchez-Guerrero, "Effect of severe neuropsychiatric manifestations on short-term damage in systemic lupus erythematosus," Journal of Rheumatology, vol. 34, no. 1, pp. 76-80, 2007.

[82] Y. Tokano, S. Morimoto, H. Amano et al., "The relationship between initial clinical manifestation and long-term prognosis of patients with systemic lupus erythematosus," Modern Rheumatology, vol. 15, no. 4, pp. 275-282, 2005.

[83] S. K. Xie, S. F. Feng, and H. Fu, "Long term follow-up of patients with systemic lupus erythematosus," Journal of Dermatology, vol. 25, no. 6, pp. 367-373, 1998.

[84] H. Q. Zhou, F. C. Zhang, X. P. Tian et al., "Clinical features and outcome of neuropsychiatric lupus in Chinese: analysis of 240 hospitalized patients," Lupus, vol. 17, no. 2, pp. 93-99, 2008.

[85] T. Abel, D. D. Gladman, and M. B. Urowitz, "Neuropsychiatric lupus," Journal of Rheumatology, vol. 7, no. 3, pp. 325333, 1980.

[86] T. Y. Zhu, L. S. Tam, V. W. Y. Lee, K. K. Lee, and E. K. Li, "Systemic lupus erythematosus with neuropsychiatric manifestation incurs high disease costs: a cost-of-illness study in Hong Kong," Rheumatology, vol. 48, no. 5, pp. 564568, 2009.

[87] I. E. M. Bultink, F. Turkstra, B. A. C. Dijkmans, and A. E. Voskuyl, "High prevalence of unemployment in patients with systemic lupus erythematosus: association with organ damage and health-related quality of life," Journal of Rheumatology, vol. 35, no. 6, pp. 1053-1057, 2008.

[88] R. Garcia-Cavazos, R. Brey, and G. L. Robert, "Neuropsychiatric systemic lupus erythematosus," in Systemic Lupus Erythematosus, pp. 757-783, Academic Press, San Diego, Calif, USA, 4th edition, 2004.

[89] J. A. Denburg, S. D. Denburg, R. M. Carbotte, B. Sakic, H. Szechtman, and S. Yehuda, "Brain, behaviour and lupus," in The Decade of Autoimmunity, pp. 127-133, Elsevier Science, Amsterdam, The Netherlands, 1999.

[90] B. Diamond, "Antibodies and the brain: lessons from lupus," Journal of Immunology, vol. 185, no. 5, pp. 2637-2640, 2010.

[91] J. G. Hanly, "Neuropsychiatric lupus," Current Rheumatology Reports, vol. 3, no. 3, pp. 205-212, 2001.

[92] P. M. Moore, "Neuropsychiatric systemic lupus erythematosus: stress, stroke, and seizures," Annals of the New York Academy of Sciences, vol. 823, pp. 1-17, 1997.

[93] T. Robinson and C. M. Neuwelt, "Neuropsychiatric lupus and hormones," Annales de Medecine Interne, vol. 147, no. 4, pp. 276-280, 1996. 
[94] S. G. West, "Lupus and the central nervous system," Current Opinion in Rheumatology, vol. 8, no. 5, pp. 408-414, 1996.

[95] R. D. Porsolt, "Animal model of depression," Biomedicine, vol. 30, no. 3, pp. 139-140, 1979.

[96] R. D. Porsolt, G. Anton, N. Blavet, and M. Jalfre, "Behavioural despair in rats: a new model sensitive to antidepressant treatments," European Journal of Pharmacology, vol. 47, no. 4, pp. 379-391, 1978.

[97] V. Castagné, P. Moser, S. Roux, and R. D. Porsolt, Rodent Models of Depression: Forced Swim and Tail Suspension Behavioral Despair Tests in Rats and Mice, John Wiley \& Sons, New York, NY, USA, 2001.

[98] R. D. Porsolt, G. Brossard, C. Hautbois, and S. Roux, Rodent Models of Depression: Forced Swimming and Tail Suspension Behavioral Despair Tests in Rats and Mice, John Wiley \& Sons, New York, NY, USA, 2001.

[99] L. A. W. Jans, G. A. H. Korte-Bouws, S. M. Korte, and A. Blokland, "The effects of acute tryptophan depletion on affective behaviour and cognition in Brown Norway and Sprague Dawley rats," Journal of Psychopharmacology, vol. 24, no. 4, pp. 605-614, 2010.

[100] E. C. Stoffel and R. M. Craft, "Ovarian hormone withdrawalinduced "depression" in female rats," Physiology and Behavior, vol. 83, no. 3, pp. 505-513, 2004.

[101] P. Willner, R. Muscat, and M. Papp, "Chronic mild stressinduced anhedonia: a realistic animal model of depression," Neuroscience and Biobehavioral Reviews, vol. 16, no. 4, pp. 525-534, 1992.

[102] B. Vollmayr and F. A. Henn, "Stress models of depression," Clinical Neuroscience Research, vol. 3, no. 4-5, pp. 245-251, 2003.

[103] A. J. Heritch, K. Henderson, and T. C. Westfall, "Effects of social isolation on brain catecholamines and forced swimming in rats: prevention by antidepressant treatment," Journal of Psychiatric Research, vol. 24, no. 3, pp. 251-258, 1990.

[104] M. Muller, J. Olivier, and J. Homberg, Eds., Knockout and Mutant Rats, vol. 44, Humana Press, 2010.

[105] D. H. Overstreet, "The Flinders Sensitive Line rats: a genetic animal model of depression," Neuroscience and Biobehavioral Reviews, vol. 17, no. 1, pp. 51-68, 1993.

[106] W. T. McKinney, "Animal models of depression: an overview," Psychiatric Developments, vol. 2, no. 2, pp. 77-96, 1984.

[107] H. Anisman and K. Matheson, "Stress, depression, and anhedonia: caveats concerning animal models," Neuroscience and Biobehavioral Reviews, vol. 29, no. 4-5, pp. 525-546, 2005.

[108] T. Strekalova, R. Spanagel, D. Bartsch, F. A. Henn, and P. Gass, "Stress-induced anhedonia in mice is associated with deficits in forced swimming and exploration," Neuropsychopharmacology, vol. 29, no. 11, pp. 2007-2017, 2004.

[109] K. K. Anderson, D. A. Ballok, N. Prasad, H. Szechtman, and B. Sakic, "Impaired response to amphetamine and neuronal degeneration in the nucleus accumbens of autoimmune MRL-lpr mice," Behavioural Brain Research, vol. 166, no. 1, pp. 32-38, 2006.

[110] E. Choleris, A. W. Thomas, M. Kavaliers, and F. S. Prato, "A detailed ethological analysis of the mouse open field test: effects of diazepam, chlordiazepoxide and an extremely low frequency pulsed magnetic field," Neuroscience and Biobehavioral Reviews, vol. 25, no. 3, pp. 235-260, 2001.

[111] S. Sacre, M. Medghalchi, B. Gregory, F. Brennan, and R. Williams, "Fluoxetine and citalopram exhibit potent antiinflammatory activity in human and murine models of rheumatoid arthritis and inhibit toll-like receptors," Arthritis and Rheumatism, vol. 62, no. 3, pp. 683-693, 2010.

[112] O. M. E. Abdel-Salam, A. R. Baiuomy, and M. S. Arbid, "Studies on the anti-inflammatory effect of fluoxetine in the rat," Pharmacological Research, vol. 49, no. 2, pp. 119-131, 2004.

[113] R. S. Lesser, J. L. Walters, R. Khan, R. Pebenito, and S. Klee, "Improvement of neuropsychiatric lupus with addition of SSRI antidepressant/antipsychotic therapy," Journal of Clinical Rheumatology, vol. 3, no. 5, pp. 294-298, 1997.

[114] M. Farrell, B. Sakic, H. Szechtman, and J. A. Denburg, "Effect of cyclophosphamide on leukocytic infiltration in the brain of MRL/lpr mice," Lupus, vol. 6, no. 3, pp. 268-274, 1997.

[115] S. Carlomagno, S. Migliaresi, L. Ambrosone, M. Sannino, G. Sanges, and G. Di Iorio, "Cognitive impairment in systemic lupus erythematosus: a follow-up study," Journal of Neurology, vol. 247, no. 4, pp. 273-279, 2000.

[116] E. M. Hay, "Psychiatric disorder and cognitive impairment in SLE," Lupus, vol. 3, no. 3, pp. 145-148, 1994.

[117] D. T. Boumpas, H. Yamada, N. J. Patronas, D. Scott, J. H. Klippel, and J. E. Balow, "Pulse cyclophosphamide for severe neuropsychiatric lupus," Quarterly Journal of Medicine, vol. 81, no. 296, pp. 975-984, 1991.

[118] A. N. Malaviya, R. R. Singh, R. Sindhwani et al., "Intermittent intravenous pulse cyclophosphamide treatment in systemic lupus erythematosus," Indian Journal of Medical Research, vol. 96, pp. 101-108, 1992.

[119] E. A. Bachen, M. A. Chesney, and L. A. Criswell, "Prevalence of mood and anxiety disorders in women with systemic lupus erythematosus," Arthritis Care and Research, vol. 61, no. 6, pp. 822-829, 2009.

[120] S. E. File, A. S. Lippa, B. Beer, and M. T. Lippa, Animal Tests of Anxiety, John Wiley \& Sons, New York, NY, USA, 2001.

[121] M. Komada, K. Takao, and T. Miyakawa, "Elevated plus maze for mice," Journal of Visualized Experiments, no. 22, 2008.

[122] S. Pellow, P. Chopin, S. E. File, and M. Briley, "Validation of open:closed arm entries in an elevated plus-maze as a measure of anxiety in the rat," Journal of Neuroscience Methods, vol. 14, no. 3, pp. 149-167, 1985.

[123] S. Hogg, "A review of the validity and variability of the elevated plus-maze as an animal model of anxiety," Pharmacology Biochemistry and Behavior, vol. 54, no. 1, pp. 21-30, 1996.

[124] C. F. Plappert and P. K. D. Pilz, "The acoustic startle response as an effective model for elucidating the effect of genes on the neural mechanism of behavior in mice," Behavioural Brain Research, vol. 125, no. 1-2, pp. 183-188, 2001.

[125] M. Koch and H. U. Schnitzler, "The acoustic startle response in rats-circuits mediating evocation, inhibition and potentiation," Behavioural Brain Research, vol. 89, no. 1-2, pp. 3549, 1997.

[126] M. Davis, D. L. Walker, and Y. Lee, "Amygdala and bed nucleus of the stria terminalis: differential roles in fear and anxiety measured with the acoustic startle reflex," Philosophical Transactions of the Royal B, vol. 352, no. 1362, pp. 1675-1687, 1997.

[127] J. S. Yeomans and P. W. Frankland, "The acoustic startle reflex: neurons and connections," Brain Research Reviews, vol. 21, no. 3, pp. 301-314, 1995.

[128] A. Ennaceur and K. Meliani, "A new one-trial test for neurobiological studies of memory in rats. III. Spatial vs. non-spatial working memory," Behavioural Brain Research, vol. 51, no. 1, pp. 83-92, 1992. 
[129] A. Ennaceur and J. Delacour, "A new one-trial test for neurobiological studies of memory in rats. 1: behavioral data," Behavioural Brain Research, vol. 31, no. 1, pp. 47-59, 1988.

[130] E. Dere, J. P. Huston, and M. A. De Souza Silva, "The pharmacology, neuroanatomy and neurogenetics of one-trial object recognition in rodents," Neuroscience and Biobehavioral Reviews, vol. 31, no. 5, pp. 673-704, 2007.

[131] Y. Nagakura, T. Oe, T. Aoki, and N. Matsuoka, "Biogenic amine depletion causes chronic muscular pain and tactile allodynia accompanied by depression: a putative animal model of fibromyalgia," Pain, vol. 146, no. 1-2, pp. 26-33, 2009.

[132] S. Chun, R. McEvilly, J. A. Foster, and B. Sakic, "Proclivity to self-injurious behavior in MRL-lpr mice: implications for autoimmunity-induced damage in the dopaminergic system," Molecular Psychiatry, vol. 13, no. 11, pp. 1043-1053, 2008.

[133] M. S. Harbuz, G. L. Conde, O. Marti, S. L. Lightman, and D. S. Jessop, "The hypothalamic-pituitary-adrenal axis in autoimmunity," Annals of the New York Academy of Sciences, vol. 823, pp. 214-224, 1997.

[134] J. Zeller, E. Weissbarth, B. Baruth, H. Mielke, and H. Deicher, "Serotonin content of platelets in inflammatory rheumatic diseases. Correlation with clinical activity," Arthritis and Rheumatism, vol. 26, no. 4, pp. 532-540, 1983.

[135] E. Maurer-Spurej, C. Pittendreigh, and S. Misri, "Platelet serotonin levels support depression scores for women with postpartum depression," Journal of Psychiatry and Neuroscience, vol. 32, no. 1, pp. 23-29, 2007.

[136] J. Quintana, "Platelet serotonin and plasma tryptophan decreases in endogenous depression. Clinical, therapeutic, and biological correlations," Journal of Affective Disorders, vol. 24, no. 2, pp. 55-62, 1992.

[137] A. Schäfer, M. Scheurlen, J. Seufert et al., "Platelet serotonin (5-HT) levels in interferon-treated patients with hepatitis C and its possible association with interferon-induced depression," Journal of Hepatology, vol. 52, no. 1, pp. 10-15, 2010.

[138] R. J. Fontana, Z. Kronfol, K. L. Lindsay et al., "Changes in mood states and biomarkers during peginterferon and ribavirin treatment of chronic hepatitis C," American Journal of Gastroenterology, vol. 103, no. 11, pp. 2766-2775, 2008.

[139] M. Bannink, W. H. J. Kruit, A. R. Van Gool et al., "Platelet MAO activity during treatment with pegylated interferon-alfa in melanoma patients," Progress in NeuroPsychopharmacology and Biological Psychiatry, vol. 29, no. 1, pp. 109-114, 2005.

[140] D. J. Stein, "Depression, anhedonia, and psychomotor symptoms: the role of dopaminergic neurocircuitry," CNS Spectrums, vol. 13, no. 7, pp. 561-565, 2008.

[141] G. Rajkowska, "Histopathology of the prefrontal cortex in major depression: what does it tell us about dysfunctional monoaminergic circuits?" Progress in Brain Research, vol. 126, pp. 397-412, 2000.

[142] T. Kobayashi, E. Hayashi, M. Shimamura, M. Kinoshita, and N. P. Murphy, "Neurochemical responses to antidepressants in the prefrontal cortex of mice and their efficacy in preclinical models of anxiety-like and depression-like behavior: a comparative and correlational study," Psychopharmacology, vol. 197, no. 4, pp. 567-580, 2008.

[143] G. Loheswaran, M. Stanojcic, L. Xu, and B. Sakic, "Autoimmunity as a principal pathogenic factor in the refined model of neuropsychiatric lupus," Clinical and Experimental Neuroimmunology, vol. 1, no. 3, pp. 141-152, 2010.
[144] S. E. File and P. Seth, "A review of 25 years of the social interaction test," European Journal of Pharmacology, vol. 463, no. 1-3, pp. 35-53, 2003.

[145] J. A. Denburg, S. D. Denburg, R. M. Carbotte, B. Sakic, and H. Szechtman, "Nervous system lupus: pathogenesis and rationale for therapy," Scandinavian Journal of Rheumatology, vol. 24, pp. 263-273, 1995.

[146] K. Deusch, R. Fernandez-Botran, M. Konstadoulakis, K. Baur, and R. S. M. P. Schwartz Madaio, "Autoreactive T cells from MRL-lpr/lpr mice secrete multiple lymphokines and induce the production of IgG anti-DNA antibodies," Journal of Autoimmunity, vol. 4, no. 4, pp. 563-576, 1991.

[147] N. B. Blatt and G. D. Glick, "Anti-DNA autoantibodies and systemic lupus erythematosus," Pharmacology and Therapeutics, vol. 83, no. 2, pp. 125-139, 1999.

[148] Z. Amoura, H. Chabre, S. Koutouzov et al., "Nucleosomerestricted antibodies are detected before anti-dsDNA and/or antihistone antibodies in serum of MRL-Mp lpr/lpr and +/+ mice, and are present in kidney eluates of lupus mice with proteinuria," Arthritis and Rheumatism, vol. 37, no. 11, pp. 1684-1688, 1994.

[149] K. B. Elkon, E. Bonfa, and N. Brot, "Antiribosomal antibodies in systemic lupus erythematosus," Rheumatic Disease Clinics of North America, vol. 18, no. 2, pp. 377-390, 1992.

[150] D. Hirata, M. Iwamoto, T. Yoshio et al., "Nucleolin as the earliest target molecule of autoantibodies produced in MRL/lpr lupus-prone mice," Clinical Immunology, vol. 97, no. 1 , pp. 50-58, 2000.

[151] S. Izui, T. Berney, T. Shibata, T. Fulpius, L. Fossati, and R. Merino, "Molecular and cellular basis for pathogenicity of autoantibodies," Tohoku Journal of Experimental Medicine, vol. 173, no. 1, pp. 15-30, 1994.

[152] D. M. D’Andrea, B. Coupaye-Gerard, T. R. Kleyman, M. H. Foster, and M. P. Madaio, "Lupus autoantibodies interact directly with distinct glomerular and vascular cell surface antigens," Kidney International, vol. 49, no. 5, pp. 1214-1221, 1996.

[153] M. P. Madaio, J. Carlson, J. Cataldo, A. Ucci, P. Migliorini, and O. Pankewycz, "Murine monoclonal anti-DNA antibodies bind directly to glomerular antigens and form immune deposits," Journal of Immunology, vol. 138, no. 9, pp. 28832889, 1987.

[154] M. Marino, M. Ruvo, S. De Falco, and G. Fassina, "Prevention of systemic lupus erythematosus in MRL/lpr mice by administration of an immunoglobulin-binding peptide," Nature Biotechnology, vol. 18, no. 7, pp. 735-739, 2000.

[155] L. Lapteva, M. Nowak, C. H. Yarboro et al., "Anti-N-methylD-aspartate receptor antibodies, cognitive dysfunction, and depression in systemic lupus erythematosus," Arthritis and Rheumatism, vol. 54, no. 8, pp. 2505-2514, 2006.

[156] J. E. Brick, S. H. Ong, J. M. Bathon, S. E. Walker, F. X. O'Sullivan, and A. G. DiBartolomeo, "Anti-histone antibodies in the serum of autoimmune MRL and NZB/NZW F mice," Clinical Immunology and Immunopathology, vol. 54, no. 3, pp. 372-381, 1990.

[157] M. G. Cohen, K. M. Pollard, and L. Schrieber, "Relationship of age and sex to autoantibody expression in MRL-+/+ and MRL-lpr/lpr mice: demonstration of an association between the expression of antibodies to histones, denatured DNA and Sm in MRL-+/+ mice," Clinical and Experimental Immunology, vol. 72, no. 1, pp. 50-54, 1988.

[158] O. Costa and J. C. Monier, "Detection of antibodies to histones in human systemic lupus erythematosus and in 
murine lupus-like syndromes using micro-ELISA," Annales d'Immunologie, vol. 134, no. 3, pp. 365-376, 1983.

[159] J. E. Brick, S. H. Ong, J. M. Bathon, S. E. Walker, F. X. O'Sullivan, and A. G. DiBartolomeo, "Anti-histone antibodies in the serum of autoimmune MRL and NZB/NZW F mice," Clinical Immunology and Immunopathology, vol. 54, no. 3, pp. 372-381, 1990.

[160] P. M. Moore, I. Joshi, and S. A. Ghanekar, "Affinity isolation of neuron-reactive antibodies in MRL/lpr mice," Journal of Neuroscience Research, vol. 39, no. 2, pp. 140-147, 1994.

[161] J. G. Hanly, J. Robichaud, and J. D. Fisk, "Anti-NR2 glutamate receptor antibodies and cognitive function in systemic lupus erythematosus," Journal of Rheumatology, vol. 33, no. 8, pp. 1553-1558, 2006.

[162] M. Stanojcic, G. Loheswaran, L. Xu, S. A. Hoffman, and B. Sakic, "Intrathecal antibodies and brain damage in autoimmune MRL mice," Brain, Behavior, and Immunity, vol. 24, no. 2, pp. 289-297, 2010.

[163] B. Sakic, H. Szechtman, J. A. Denburg, G. Gorny, B. Kolb, and I. Q. Whishaw, "Progressive atrophy of pyramidal neuron dendrites in autoimmune MRL-lpr mice," Journal of Neuroimmunology, vol. 87, no. 1-2, pp. 162-170, 1998.

[164] D. A. Ballok, J. Woulfe, M. Sur, M. Cyr, and B. Sakic, "Hippocampal damage in mouse and human forms of systemic autoimmune disease," Hippocampus, vol. 14, no. 5, pp. 649-661, 2004.

[165] B. Sakic, B. Kolb, I. Q. Whishaw, G. Gorny, H. Szechtman, and J. A. Denburg, "Immunosuppression prevents neuronal atrophy in lupus-prone mice: evidence for brain damage induced by autoimmune disease?" Journal of Neuroimmunology, vol. 111, no. 1-2, pp. 93-101, 2000.

[166] D. A. Ballok, J. M. Millward, and B. Sakic, "Neurodegeneration in autoimmune MRL-lpr mice as revealed by Fluoro Jade B staining," Brain Research, vol. 964, no. 2, pp. 200-210, 2003.

[167] M. Stanojcic, T. Burstyn-Cohen, N. Nashi, G. Lemke, and B. Sakic, "Disturbed distribution of proliferative brain cells during lupus-like disease," Brain, Behavior, and Immunity, vol. 23, no. 7, pp. 1003-1013, 2009.

[168] H. Fragoso-Loyo, J. Cabiedes, A. Orozco-Narvaez et al., "Serum and cerebrospinal fluid autoantibodies in patients with neuropsychiatric lupus erythematosus. Implications for diagnosis and pathogenesis," PLoS One, vol. 3, no. 10, Article ID e3347, 2008.

[169] B. Sakic, D. L. Kirkham, D. A. Ballok et al., "Proliferating brain cells are a target of neurotoxic CSF in systemic autoimmune disease," Journal of Neuroimmunology, vol. 169, no. 1-2, pp. 68-85, 2005.

[170] H. Fragoso-Loyo, J. Cabiedes, Y. Richard-Patin et al., "Inflammatory profile in the cerebrospinal fluid of patients with central neuropsychiatric lupus, with and without associated factors," Rheumatology, vol. 48, no. 12, pp. 1615-1616, 2009.

[171] C. Kowal, L. A. DeGiorgio, T. Nakaoka et al., "Cognition and immunity: antibody impairs memory," Immunity, vol. 21, no. 2, pp. 179-188, 2004.

[172] C. Kowal, L. A. DeGiorgio, J. Y. Lee et al., "Human lupus autoantibodies against NMDA receptors mediate cognitive impairment," Proceedings of the National Academy of Sciences of the United States of America, vol. 103, no. 52, pp. 1985419859, 2006.

[173] P. T. Huerta, C. Kowal, L. A. DeGiorgio, B. T. Volpe, and B. Diamond, "Immunity and behavior: antibodies alter emotion," Proceedings of the National Academy of Sciences of the United States of America, vol. 103, no. 3, pp. 678-683, 2006.

[174] A. Katzav, I. Solodeev, O. Brodsky et al., "Induction of autoimmune depression in mice by anti-ribosomal $\mathrm{P}$ antibodies via the limbic system," Arthritis and Rheumatism, vol. 56, no. 3, pp. 938-948, 2007.

[175] R. Omdal, K. Brokstad, K. Waterloo, W. Koldingsnes, R. Jonsson, and S. I. Mellgren, "Neuropsychiatric disturbances in SLE are associated with antibodies against NMDA receptors," European Journal of Neurology, vol. 12, no. 5, pp. 392-398, 2005.

[176] M. J. Harrison, L. D. Ravdin, and M. D. Lockshin, "Relationship between serum NR2a antibodies and cognitive dysfunction in systemic lupus erythematosus," Arthritis and Rheumatism, vol. 54, no. 8, pp. 2515-2522, 2006.

[177] L. A. DeGiorgio, K. N. Konstantinov, S. C. Lee, J. A. Hardin, B. T. Volpe, and B. Diamond, "A subset of lupus anti-DNA antibodies cross-reacts with the NR2 glutamate receptor in systemic lupus erythematosus," Nature Medicine, vol. 7, no. 11, pp. 1189-1193, 2001.

[178] J. J. Alexander, L. Bao, A. Jacob, D. M. Kraus, V. M. Holers, and R. J. Quigg, "Administration of the soluble complement inhibitor, Crry-Ig, reduces inflammation and aquaporin 4 expression in lupus cerebritis," Biochimica et Biophysica Acta, vol. 1639, no. 3, pp. 169-176, 2003.

[179] A. Jacob, B. Hack, E. Chiang, J. G. N. Garcia, R. J. Quigg, and J. J. Alexander, "C5a alters blood-brain barrier integrity in experimental lupus," FASEB Journal, vol. 24, no. 6, pp. 1682$1688,2010$.

[180] X. Ma, J. Foster, and B. Sakic, "Distribution and prevalence of leukocyte phenotypes in brains of lupus-prone mice," Journal of Neuroimmunology, vol. 179, no. 1-2, pp. 26-36, 2006.

[181] J. B. Winfield, M. Shaw, and L. M. Silverman, "Intrathecal IgG synthesis and blood-brain barrier impairment in patients with systemic lupus erythematosus and central nervous system dysfunction," American Journal of Medicine, vol. 74 , no. 5, pp. 837-844, 1983.

[182] M. Wichers and M. Maes, "The psychoneuroimmunopathophysiology of cytokine-induced depression in humans," International Journal of Neuropsychopharmacology, vol. 5, no. 4, pp. 375-388, 2002.

[183] R. Dantzer, "Cytokine, sickness behavior, and depression," Immunology and Allergy Clinics of North America, vol. 29, no. 2, pp. 247-264, 2009.

[184] H. Anisman, L. Kokkinidis, and Z. Merali, "Further evidence for the depressive effects of cytokines: anhedonia and neurochemical changes," Brain, Behavior, and Immunity, vol. 16, no. 5, pp. 544-556, 2002.

[185] E. Kozora, M. Laudenslager, A. Lemieux, and S. G. West, "Inflammatory and hormonal measures predict neuropsychological functioning in systemic lupus erythematosus and rheumatoid arthritis patients," Journal of the International Neuropsychological Society, vol. 7, no. 6, pp. 745-754, 2001.

[186] M. Tomita, B. J. Holman, and T. J. Santoro, "Aberrant cytokine gene expression in the hippocampus in murine systemic lupus erythematosus," Neuroscience Letters, vol. 302, no. 2-3, pp. 129-132, 2001.

[187] C. Haas, B. Ryffel, and M. Le Hir, "IFN- $\gamma$ is essential for the development of autoimmune glomerulonephritis in MRL/lpr mice," Journal of Immunology, vol. 158, no. 11, pp. 54845491, 1997.

[188] D. G. Alleva, S. B. Kaser, and D. I. Beller, "Aberrant cytokine expression and autocrine regulation characterize 
macrophages from young mrl+/+ and nzb/w f1 lupus-prone mice," Journal of Immunology, vol. 159, no. 11, pp. 5610 5619, 1997.

[189] C. E. Carvalho-Pinto, M. I. García, M. Mellado et al., "Autocrine production of IFN- $\gamma$ by macrophages controls their recruitment to kidney and the development of glomerulonephritis in MRL/lpr mice," Journal of Immunology, vol. 169, no. 2, pp. 1058-1067, 2002.

[190] A. Shirai, J. Conover, and D. M. Klinman, "Increased activation and altered ratio of interferon-gamma: interleukin-4 secreting cells in MRL-lpr/lpr mice," Autoimmunity, vol. 21, no. 2, pp. 107-116, 1995.

[191] A. Schwarting, K. Paul, S. Tschirner et al., "Interferon- $\beta$ : a therapeutic for autoimmune lupus in MRL-Fas mice," Journal of the American Society of Nephrology, vol. 16, no. 11, pp. 3264-3272, 2005.

[192] Y. Asanuma, K. Nagai, M. Kato, H. Sugiura, and S. Kawai, "Weekly pulse therapy of methotrexate improves survival compared with its daily administration in MRL/lpr mice," European Journal of Pharmacology, vol. 435, no. 2-3, pp. 253258, 2002.

[193] V. Best, P. Ruiz, and R. F. Spurney, "The prostaglandin e(1) (pge(1)) analog misoprostol ameliorates autoimmune disease and depletes t lymphocytes in mrl-lpr/lpr mice," American Journal of Therapeutics, vol. 2, pp. 943-948, 1995.

[194] J. H. M. Berden, P. Faaber, K. J. M. Assmann, and T. P. M. Rijke, "Effects of cyclosporin A on autoimmune disease in MRL/1 and BXSB mice," Scandinavian Journal of Immunology, vol. 24, no. 4, pp. 405-412, 1986.

[195] M. Mihara, A. Katsume, and Y. Takeda, "Effect of methotrexate treatment on the onset of autoimmune kidney disease in lupus mice," Chemical and Pharmaceutical Bulletin, vol. 40, no. 8, pp. 2177-2181, 1992.

[196] R. P. Carlson, S. C. Gilman, T. G. Hodge, L. O’Neill-Davis, E. M. Blazek, and A. J. Lewis, "Effects of oral aspirin and oxaprozin on the development of lupus-like disease in MRL/1 mice," Journal of Immunopharmacology, vol. 6, no. 1-2, pp. 69-78, 1984.

[197] L. D. Apelgren, D. L. Bailey, R. L. Fouts et al., "The effect of a selective estrogen receptor modulator on the progression of spontaneous autoimmune disease in MRL lpr/lpr mice," Cellular Immunology, vol. 173, no. 1, pp. 55-63, 1996.

[198] R. Lake and N. Staines, "DNA-induced antibodies derived from autoimmune MRL mice fail to induce clinical changes when administered to healthy animals," Agents and Actions, vol. 19, no. 5-6, pp. 306-308, 1986.

[199] S. A. Hoffman, D. N. Arbogast, P. M. Ford, D. W. Shucard, and R. J. Harbeck, "Brain-reactive autoantibody levels in the sera of ageing autoimmune mice," Clinical and Experimental Immunology, vol. 70, no. 1, pp. 74-83, 1987.

[200] O. T. M. Chan, L. G. Hannum, A. M. Haberman, M. P. Madaio, and M. J. Shlomchik, "A novel mouse with B cells but lacking serum antibody reveals an antibody-independent role for B cells in murine lupus," Journal of Experimental Medicine, vol. 189, no. 10, pp. 1639-1647, 1999.

[201] R. Dantzer and K. W. Kelley, "Twenty years of research on cytokine-induced sickness behavior," Brain, Behavior, and Immunity, vol. 21, no. 2, pp. 153-160, 2007.

[202] H. Anisman and Z. Merali, "Cytokines, stress, and depressive illness," Brain, Behavior, and Immunity, vol. 16, no. 5, pp. 513-524, 2002.

[203] S. Chourbaji, A. Urani, I. Inta et al., "IL-6 knockout mice exhibit resistance to stress-induced development of depression-like behaviors," Neurobiology of Disease, vol. 23, no. 3, pp. 587-594, 2006.

[204] R. De La Garza, “Endotoxin- or pro-inflammatory cytokineinduced sickness behavior as an animal model of depression: focus on anhedonia," Neuroscience and Biobehavioral Reviews, vol. 29, no. 4-5, pp. 761-770, 2005.

[205] D. B. Miller and J. P. O'Callaghan, "Depression, cytokines, and glial function," Metabolism, vol. 54, no. 5, pp. 33-38, 2005.

[206] A. D. Basterzi, C. Aydemir, C. Kisa et al., "IL-6 levels decrease with SSRI treatment in patients with major depression," Human Psychopharmacology, vol. 20, no. 7, pp. 473-476, 2005.

[207] D. Lindqvist, S. Janelidze, P. Hagell et al., "Interleukin-6 is elevated in the cerebrospinal fluid of suicide attempters and related to symptom severity," Biological Psychiatry, vol. 66, no. 3, pp. 287-292, 2009.

[208] T. G. Dinan, "Inflammatory markers in depression," Current Opinion in Psychiatry, vol. 22, no. 1, pp. 32-36, 2009.

[209] C. L. Raison, L. Capuron, and A. H. Miller, "Cytokines sing the blues: inflammation and the pathogenesis of depression," Trends in Immunology, vol. 27, no. 1, pp. 24-31, 2006.

[210] N. I. Eisenberger, T. K. Inagaki, N. M. Mashal, and M. R. Irwin, "Inflammation and social experience: an inflammatory challenge induces feelings of social disconnection in addition to depressed mood," Brain, Behavior, and Immunity, vol. 24, no. 4, pp. 558-563, 2010.

[211] J. M. Loftis, M. Huckans, and B. J. Morasco, "Neuroimmune mechanisms of cytokine-induced depression: current theories and novel treatment strategies," Neurobiology of Disease, vol. 37, no. 3, pp. 519-533, 2010.

[212] O. J. G. Schiepers, M. C. Wichers, and M. Maes, "Cytokines and major depression," Progress in NeuroPsychopharmacology and Biological Psychiatry, vol. 29, no. 2, pp. 201-217, 2005.

[213] M. Maes, "The cytokine hypothesis of depression: inflammation, oxidative \& nitrosative stress (IO\&NS) and leaky gut as new targets for adjunctive treatments in depression," Neuroendocrinology Letters, vol. 29, no. 3, pp. 287-291, 2008.

[214] A. George-Chandy, E. Trysberg, and K. Eriksson, "Raised intrathecal levels of APRIL and BAFF in patients with systemic lupus erythematosus: relationship to neuropsychiatric symptoms," Arthritis Research and Therapy, vol. 10, no. 4, Article ID R97, 2008.

[215] E. Svenungsson, M. Andersson, L. Brundin et al., "Increased levels of proinflammatory cytokines and nitric oxide metabolites in neuropsychiatric lupus erythematosus," Annals of the Rheumatic Diseases, vol. 60, no. 4, pp. 372-379, 2001.

[216] Y. Choi, K. Simon-Stoos, and J. M. Puck, "Hypo-active variant of IL-2 and associated decreased T cell activation contribute to impaired apoptosis in autoimmune prone MRL mice," European Journal of Immunology, vol. 32, no. 3, pp. 677-685, 2002.

[217] S. Lemay, C. Mao, and A. K. Singh, "Cytokine gene expression in the MRL/lpr model of lupus nephritis," Kidney International, vol. 50, no. 1, pp. 85-93, 1996.

[218] F. P. Huang and D. I. Stott, "Restoration of an early, progressive defect in responsiveness to $\mathrm{T}$-cell activation in lupus mice by exogenous IL-2," Autoimmunity, vol. 15, no. 1, pp. 19-29, 1993.

[219] M. L. Huggins, F. P. Huang, D. Xu, G. Lindop, and D. I. Stott, "Modulation of autoimmune disease in the MRL-lpr/lpr mouse by IL- 2 and TGF- $\beta$ gene therapy using attenuated 
Salmonella typhimurium as gene carrier," Lupus, vol. 8, no. 1, pp. 29-38, 1999.

[220] T. J. Santoro, W. R. Benjamin, J. J. Oppenheim, and A. D. Steinberg, "The cellular basis for immune interferon production in autoimmune MRL-Ipr/Ipr mice," Journal of Immunology, vol. 131, no. 1, pp. 265-268, 1983.

[221] G. Pérez de Lema, H. Maier, E. Nieto et al., "Chemokine expression precedes inflammatory cell infiltration and chemokine receptor and cytokine expression during the initiation of murine lupus nephritis," Journal of the American Society of Nephrology, vol. 12, no. 7, pp. 1369-1382, 2001.

[222] A. N. Theofilopoulos, G. J. Prud'Homme, and F. J. Dixon, "Autoimmune aspects of systemic lupus erythematosus," Concepts in Immunopathology, vol. 1, pp. 190-218, 1985.

[223] B. Tang, T. Matsuda, S. Akira et al., "Age-associated increase in interleukin 6 in MRL/lpr mice," International Immunology, vol. 3, no. 3, pp. 273-278, 1991.

[224] P. Malek-Ahmadi and R. C. Hilsabeck, "Neuropsychiatric complications of interferons: classification, neurochemical bases, and management," Annals of Clinical Psychiatry, vol. 19, no. 2, pp. 113-123, 2007.

[225] A. A. Prather, M. Rabinovitz, B. G. Pollock, and F. E. Lotrich, "Cytokine-induced depression during IFN- $\alpha$ treatment: the role of IL-6 and sleep quality," Brain, Behavior, and Immunity, vol. 23, no. 8, pp. 1109-1116, 2009.

[226] J. M. Loftis and P. Hauser, "The phenomenology and treatment of interferon-induced depression," Journal of Affective Disorders, vol. 82, no. 2, pp. 175-190, 2004.

[227] G. M. Asnis, R. De la Garza, S. R. Kohn, J. F. Reinus, M. Henderson, and J. Shah, "IFN-induced depression: a role for NSAIDs," Psychopharmacology Bulletin, vol. 37, no. 3, pp. 2950, 2003.

[228] A. M. Myint, M. J. Schwarz, H. W. M. Steinbusch, and B. E. Leonard, "Neuropsychiatric disorders related to interferon and interleukins treatment," Metabolic Brain Disease, vol. 24, no. 1, pp. 55-68, 2009.

[229] R. A. Asherson, S. D. Denburg, J. A. Denburg, R. M. Carbotte, and N. Futrell, "Current concepts of neuropsychiatric systemic lupus erythematosus (NP-SLE)," Postgraduate Medical Journal, vol. 69, no. 814, pp. 602-608, 1993.

[230] N. Sugiyama, H. Nakashima, T. Yoshimura et al., "Amelioration of human lupus-like phenotypes in MRL/lpr mice by overexpression of interleukin 27 receptor $\alpha$ (WSX-1)," Annals of the Rheumatic Diseases, vol. 67, no. 10, pp. 1461-1467, 2008.

[231] F. Favilli, C. Anzilotti, L. Martinelli et al., "IL-18 activity in systemic lupus erythematosus," Annals of the New York Academy of Sciences, vol. 1173, pp. 301-309, 2009.

[232] H. Cash, M. Relle, J. Menke et al., "Interleukin 6 (IL6) deficiency delays lupus nephritis in MRL-Fas mice: the IL-6 pathway as a new therapeutic target in treatment of autoimmune kidney disease in systemic lupus erythematosus," Journal of Rheumatology, vol. 37, no. 1, pp. 60-70, 2010.

[233] E. Esfandiari, I. B. McInnes, G. Lindop et al., "A proinflammatory role of IL-18 in the development of spontaneous autoimmune disease," Journal of Immunology, vol. 167, no. 9, pp. 5338-5347, 2001.

[234] N. Kim, L. Ussin, X. Cheng, R. Murali, and K. E. Sullivan, "TNF $\alpha$ inhibition in MRL/lpr mice ameliorates pulmonary but not renal disease," Journal of Autoimmunity, vol. 19, no. 4, pp. 215-222, 2002.

[235] J. D. Hron and S. L. Peng, “Type I IFN protects against murine lupus," Journal of Immunology, vol. 173, no. 3, pp. 2134-2142, 2004.
[236] Z. Yin, G. Bahtiyar, N. Zhang et al., "IL-10 regulates murine lupus," Journal of Immunology, vol. 169, no. 4, pp. 2148-2155, 2002.

[237] D. Herber, T. P. Brown, S. Liang, D. A. Young, M. Collins, and K. Dunussi-Joannopoulos, "IL-21 has a pathogenic role in a lupus-prone mouse model and its blockade with IL-21R.Fc reduces disease progression," Journal of Immunology, vol. 178, no. 6, pp. 3822-3830, 2007.

[238] H. Cash, M. Relle, J. Menke et al., "Interleukin 6 (IL6) deficiency delays lupus nephritis in MRL-Fas mice: the IL-6 pathway as a new therapeutic target in treatment of autoimmune kidney disease in systemic lupus erythematosus," Journal of Rheumatology, vol. 37, no. 1, pp. 60-70, 2010.

[239] A. Altman, A. N. Theofilopoulos, and R. Weiner, "Analysis of $\mathrm{T}$ cell function in autoimmune murine strains. Defects in production of and responsiveness to interleukin 2," Journal of Experimental Medicine, vol. 154, no. 3, pp. 791-808, 1981.

[240] H. Suzuki, K. Yasukawa, T. Saito et al., "Serum soluble interleukin-6 receptor in MRL/lpr mice is elevated with age and mediates the interleukin-6 signal," European Journal of Immunology, vol. 23, no. 5, pp. 1078-1082, 1993.

[241] L. H. Tonelli, A. Holmes, and T. T. Postolache, "Intranasal immune challenge induces sex-dependent depressive-like behavior and cytokine expression in the brain," Neuropsychopharmacology, vol. 33, no. 5, pp. 1038-1048, 2008.

[242] T. H. Wu and C. H. Lin, "IL-6 mediated alterations on immobile behavior of rats in the forced swim test via ERK1/2 activation in specific brain regions," Behavioural Brain Research, vol. 193, no. 2, pp. 183-191, 2008.

[243] B. B. Simen, C. H. Duman, A. A. Simen, and R. S. Duman, "TNF $\alpha$ signaling in depression and anxiety: behavioral consequences of individual receptor targeting," Biological Psychiatry, vol. 59, no. 9, pp. 775-785, 2006.

[244] W. B. Veldhuis, S. Floris, P. H. Van der Meide et al., "Interferon-beta prevents cytokine-induced neutrophil infiltration and attenuates blood-brain barrier disruption," Journal of Cerebral Blood Flow and Metabolism, vol. 23, no. 9, pp. 1060-1069, 2003.

[245] A. Saija, P. Princi, M. Lanza, M. Scalese, E. Aramnejad, and A. De Sarro, "Systemic cytokine administration can affect blood-brain barrier permeability in the rat," Life Sciences, vol. 56, no. 10, pp. 775-784, 1995.

[246] J. S. Koh, Z. Wang, and J. S. Levine, "Cytokine dysregulation induced by apoptotic cells is a shared characteristic of murine lupus," Journal of Immunology, vol. 165, no. 8, pp. 4190-4201, 2000.

[247] J. McAfoose and B. T. Baune, "Evidence for a cytokine model of cognitive function," Neuroscience and Biobehavioral Reviews, vol. 33, no. 3, pp. 355-366, 2009.

[248] P. C. Baier, U. May, J. Scheller, S. Rose-John, and T. Schiffelholz, "Impaired hippocampus-dependent and -independent learning in IL-6 deficient mice," Behavioural Brain Research, vol. 200, no. 1, pp. 192-196, 2009.

[249] M. F. Mehler and J. A. Kessler, "Cytokines in brain development and function," Advances in Protein Chemistry, vol. 52, pp. 223-251, 1998.

[250] J. E. Merrill, "Tumor necrosis factor alpha, interleukin 1 and related cytokines in brain development: normal and pathological," Developmental Neuroscience, vol. 14, no. 1, pp. 1-10, 1992.

[251] A. A. Ostanin, B. I. Aizikovich, I. V. Aizikovich, A. Y. Kozhin, and E. R. Chernykh, "Role of cytokines in the regulation of reproductive function," Bulletin of Experimental Biology and Medicine, vol. 143, no. 1, pp. 75-79, 2007. 
[252] S. Nayak and R. W. Herzog, "Progress and prospects: immune responses to viral vectors," Gene Therapy, vol. 17, no. 3, pp. 295-304, 2010.

[253] M. M. Sidor, B. Sakic, P. M. Malinowski, D. A. Ballok, C. J. Oleschuk, and J. MacRi, "Elevated immunoglobulin levels in the cerebrospinal fluid from lupus-prone mice," Journal of Neuroimmunology, vol. 165, no. 1-2, pp. 104-113, 2005.

[254] J. F. G. Cohen-Solal, V. Jeganathan, L. Hill et al., "Hormonal regulation of B-cell function and systemic lupus erythematosus," Lupus, vol. 17, no. 6, pp. 528-532, 2008.

[255] H. Carlsten, N. Nilsson, R. Jonsson, K. Backman, R. Holmdahl, and A. Tarkowski, "Estrogen accelerates immune complex glomerulonephritis but ameliorates T cell-mediated vasculitis and sialadenitis in autoimmune MRL lpr/lpr mice," Cellular Immunology, vol. 144, no. 1, pp. 190-202, 1992.

[256] H. Carlsten, N. Nilsson, R. Jonsson, and A. Tarkowski, "Differential effects of oestrogen in murine lupus: acceleration of glomerulonephritis and amelioration of T cell-mediated lesions," Journal of Autoimmunity, vol. 4, no. 6, pp. 845-856, 1991.

[257] H. Carlsten, A. Tarkowski, R. Holmdahl, and L. A. Nilsson, "Oestrogen is a potent disease accelerator in SLE-prone MRL $1 \mathrm{pr} / 1 \mathrm{pr}$ mice," Clinical and Experimental Immunology, vol. 80, no. 3, pp. 467-473, 1990.

[258] F. Feng, J. Nyland, M. Banyai, A. Tatum, A. E. Silverstone, and J. Gavalchin, "The induction of the lupus phenotype by estrogen is via an estrogen receptor- $\alpha$-dependent pathway," Clinical Immunology, vol. 134, no. 2, pp. 226-236, 2010.

[259] D. A. González, B. B. Díaz, M. D. C. Rodríguez Pérez, A. G. Hernández, B. N. D. Chico, and A. C. de León, "Sex hormones and autoimmunity," Immunology Letters, vol. 133, no. 1, pp. 6-13, 2010.

[260] C. M. Grimaldi, L. Hill, X. Xu, E. Peeva, and B. Diamond, "Hormonal modulation of B cell development and repertoire selection," Molecular Immunology, vol. 42, no. 7, pp. 811-820, 2005.

[261] G. M. Kammer, J. L. Marianne, P. B. John et al., "Estrogen, signal transduction, and systemic lupus erythematosus: molecular mechanisms," in Principles of Gender-Specific Medicine, pp. 1082-1092, Academic Press, San Diego, Calif, USA, 2004.

[262] N. Kanda, T. Tsuchida, and K. Tamaki, "Estrogen enhancement of anti-double-stranded dna antibody and immunoglobulin g production in peripheral blood mononuclear cells from patients with systemic lupus erythematosus," Arthritis and Rheumatism, vol. 42, no. 2, pp. 328-337, 1999.

[263] R. G. Lahita, "The role of sex hormones in systemic lupus erythematosus," Current Opinion in Rheumatology, vol. 11, no. 5, pp. 352-356, 1999.

[264] Y. Y. Dhaher, B. D. Greenstein, M. A. Khamashta, and G. R. V. Hughes, "Effects of oestradiol and the oestrogen antagonist Ici 182,780 on the delayed type hypersensitivity (DTH) index and on serum levels of $\operatorname{IgM}$ and $\operatorname{IgG}$ in ovariectomised $\mathrm{Balb} / \mathrm{C}$ and MRL/Mp-Lpr/Lpr mice, a model of systemic lupus erythematosus (SLE)," Autoimmunity, vol. 33, no. 4, pp. 237-243, 2001.

[265] F. Feng, J. Nyland, M. Banyai, A. Tatum, A. E. Silverstone, and J. Gavalchin, "The induction of the lupus phenotype by estrogen is via an estrogen receptor- $\alpha$-dependent pathway," Clinical Immunology, vol. 134, no. 2, pp. 226-236, 2010.

[266] W. M. Wu, J. L. Suen, B. F. Lin, and B. L. Chiang, "Tamoxifen alleviates disease severity and decreases double negative $\mathrm{T}$ cells in autoimmune MRL-lpr/lpr mice," Immunology, vol. 100, no. 1, pp. 110-118, 2000.

[267] D. N. Krause, S. P. Duckles, and D. A. Pelligrino, "Influence of sex steroid hormones on cerebrovascular function," Journal of Applied Physiology, vol. 101, no. 4, pp. 1252-1261, 2006.

[268] M. J. Cipolla, J. A. Godfrey, and M. J. Wiegman, "The effect of ovariectomy and estrogen on penetrating brain arterioles and blood-brain barrier permeability," Microcirculation, vol. 16, no. 8, pp. 685-693, 2009.

[269] H. M. Lee, H. Sugino, and N. Nishimoto, "Cytokine networks in systemic lupus erythematosus," Journal of Biomedicine and Biotechnology, vol. 2010, Article ID 676284, 2010.

[270] Z. M. Lu, Z. E. Wang, Y. Q. Liu et al., "Association of estrogen receptor $\alpha$ gene polymorphisms with cytokine genes expression in systemic lupus erythematosus," Croatian Medical Journal, vol. 50, no. 2, pp. 117-123, 2009.

[271] M.-A. Arevalo, M. Santos-Galindo, M.-J. Bellini et al., "Actions of estrogens on glial cells: implications for neuroprotection," Biochimica et Biophysica Acta, vol. 1800, no. 10, pp. 1106-1112, 2010.

[272] S. Arnold and C. Beyer, "Neuroprotection by estrogen in the brain: the mitochondrial compartment as presumed therapeutic target," Journal of Neurochemistry, vol. 110, no. 1, pp. 1-11, 2009.

[273] S. C. Correia, R. X. Santos, S. Cardoso et al., "Effects of estrogen in the brain: Is it a neuroprotective agent in alzheimer's disease?" Current Aging Science, vol. 3, no. 2, pp. 113-126, 2010.

[274] P. S. Herson, I. P. Koerner, and P. D. Hurn, "Sex, sex steroids, and brain injury," Seminars in Reproductive Medicine, vol. 27, no. 3, pp. 229-239, 2009.

[275] M. Liu, M. H. Kelley, P. S. Herson, and P. D. Hurn, "Neuroprotection of sex steroids," Minerva Endocrinologica, vol. 35, no. 2, pp. 127-143, 2010.

[276] W. N. McKenzie Jr., E. V. Sunderrajan, J. L. Kavanaugh, S. R. Braun, L. Ansbacher, and S. E. Walker, "Sex hormones modulate the response of pulmonary perivascular inflammation to cyclophosphamide therapy in MRL/MpJ-lpr/lpr mice," American Journal of Pathology, vol. 131, no. 3, pp. 530538, 1988.

[277] M. Cutolo, S. Capellino, A. Sulli et al., "Estrogens and autoimmune diseases," Annals of the New York Academy of Sciences, vol. 1089, pp. 538-547, 2006.

[278] C. Dalla, P. M. Pitychoutis, N. Kokras, and Z. PapadopoulouDaifoti, "Sex differences in animal models of depression and antidepressant response," Basic and Clinical Pharmacology and Toxicology, vol. 106, no. 3, pp. 226-233, 2010.

[279] P. M. Pitychoutis, E. Griva, K. Ioannou, O. E. Tsitsilonis, and Z. Papadopoulou-Daifoti, "Chronic antidepressant treatment exerts sexually dimorphic immunomodulatory effects in an experimental model of major depression: do females lack an advantage?" International Journal of Neuropsychopharmacology, vol. 12, pp. 1157-1163, 2009. 


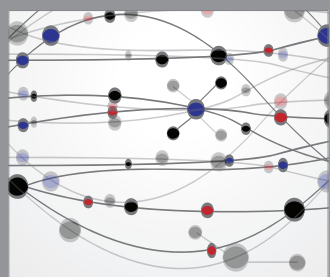

The Scientific World Journal
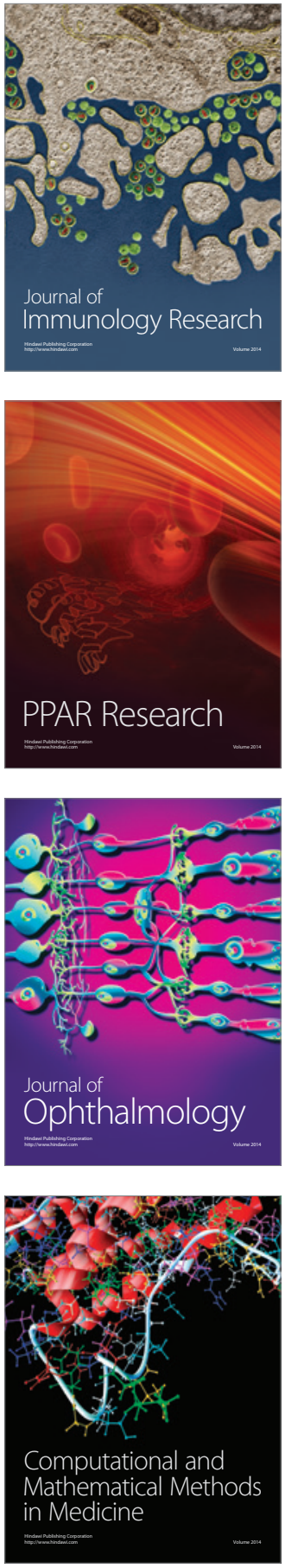

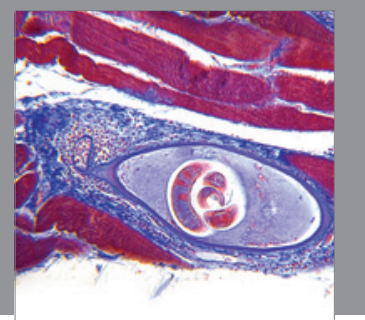

Gastroenterology

Research and Practice
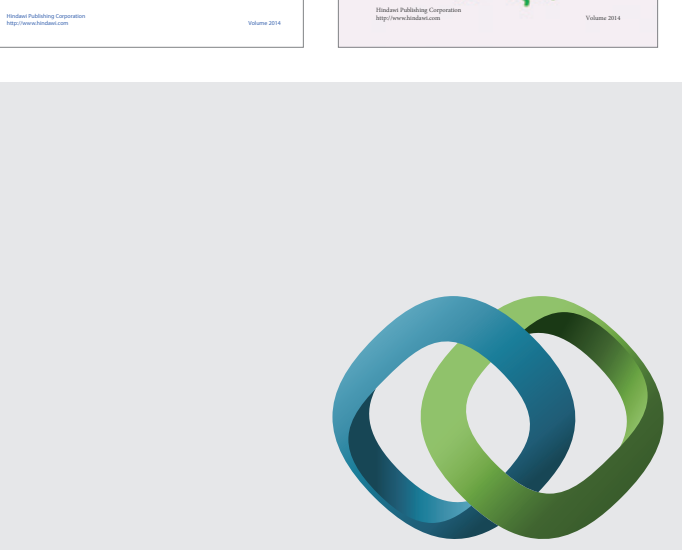

\section{Hindawi}

Submit your manuscripts at

http://www.hindawi.com
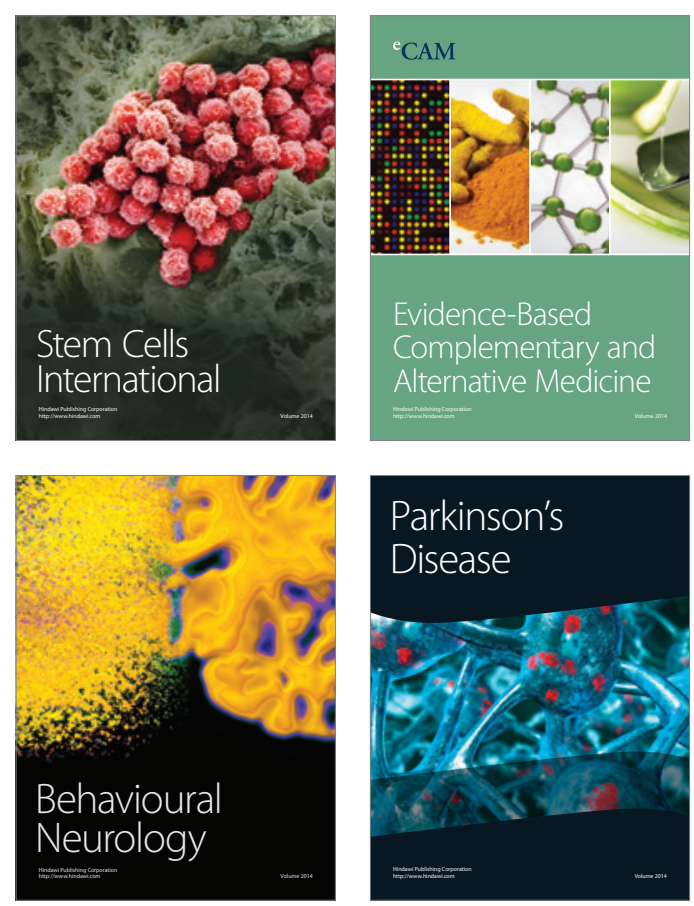

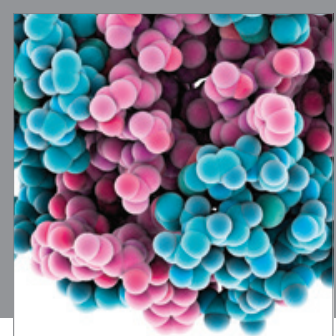

Journal of
Diabetes Research

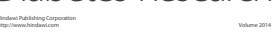

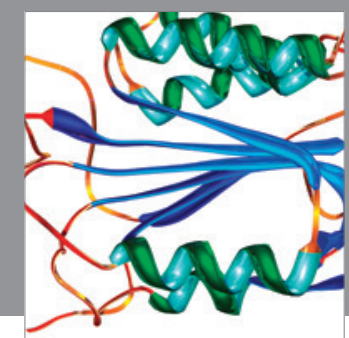

Disease Markers
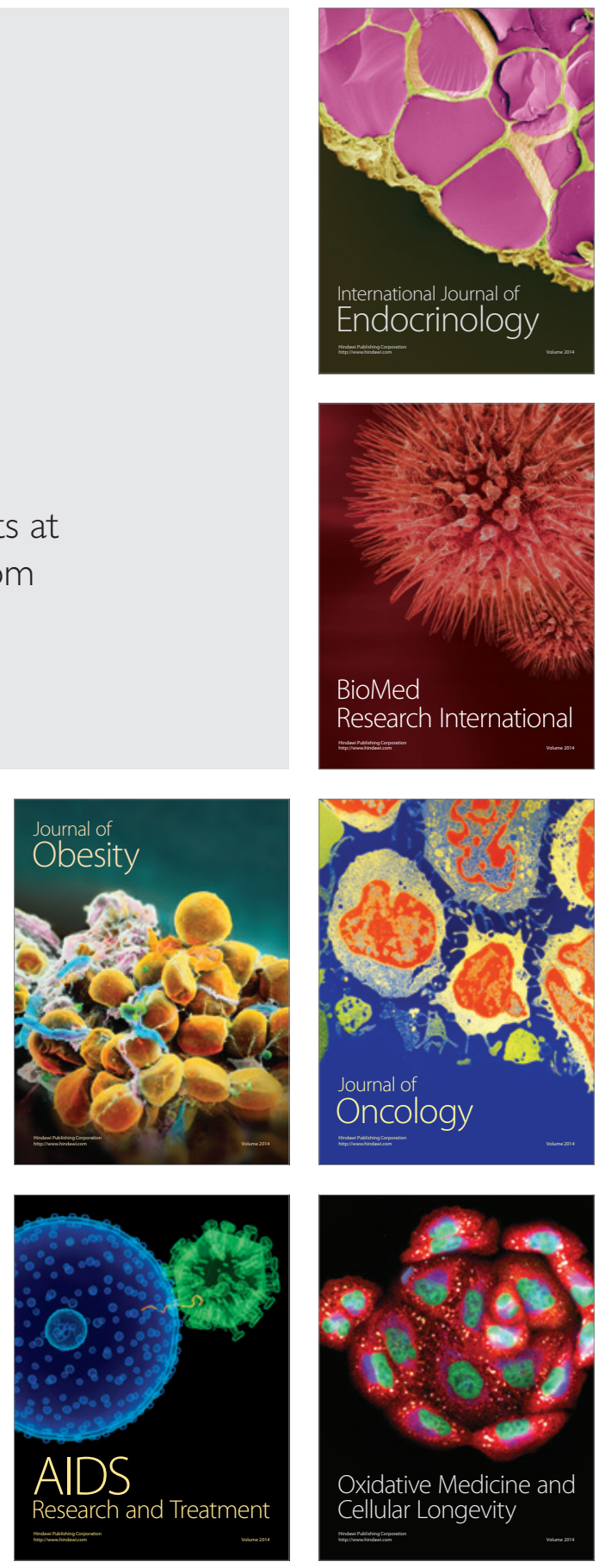